\title{
Panopticon of the Slovak Judiciary - Continuity of Power Centers and Mental Dependence
}

\author{
Peter Čurošº \\ ${ }^{1}$ Faculty of Law, University of Oslo, Oslo, Norway \\ Corresponding author: peter.curos@jus.uio.no
}

(Received 13 September 2021; accepted 20 September 2021)

\begin{abstract}
This Article explores the similarities between the principles which guide the judiciary nowadays and those typical for the functioning of the Communist justice system, particularly the susceptibility to obedience to the requests, orders, or meeting anticipations. The habitus of the judges typical for the authoritarian regime has persisted until these days and was the main reason for the judicial corruption revealed in the "Threema scandal." This Article's argument does not connect the judiciary's dependency to the Communist legacy embodied in members of the judiciary who served before 1989 and are active today. Still, the argument presumes that the Communist heritage is a key to understanding the current situation. The past heritage is hidden in the habitus of the agents or members of the judiciary. This habitus may be unconscious yet defining for the behavior of the agents. The Article aims to identify which continuities of the judicial habitus are apparent in the current judiciary. To demonstrate changes in the position of the judiciary, it presents a thesis of the development of the judiciary from an instrument of the governing party in maintaining a homogenous and subordinated society to the current situation of the Slovak judiciary, defined as a crisis of mental independence resulting in inappropriate behavior and corruption.
\end{abstract}

Keywords: Continuities and discontinuities; Slovak judiciary; informal institutions; habitus; panopticon

\section{A. Introduction}

In August 2019, Slovak newspapers first published articles on the communications of the infamous businessman Marian Kočner using the Threema application. Kočner was recently sentenced to nineteen years in prison for the forgery of TV Markíza promissory notes, ${ }^{1}$ and he faces charges for ordering the murder of investigative journalist Ján Kuciak and his fiancée, Martina Kušnírová. ${ }^{2}$ After seizing Kočner's phone, the Slovak police and the Europol decoded encrypted messages that Kočner had sent through Threema between September, 2017, and May, 2018. The uncovered

JUDr. Peter Čuroš, PhD., is a postdoctoral fellow at Institutt for Privatrett, Univeristetet i Oslo (Norway). He is also a member of the project Judges under Stress - The Breaking Point of Judicial Institutions Project. The project is financed by the FRIPRO program of the Norwegian Research Council and the University of Oslo (2019-2022).

${ }^{1}$ Judgment of the Specialised Criminal Court from February 27, 2020, PK-1T/9/2019 (Slov.).

${ }^{2}$ Monica Tódová, Kočner v Threeme: Kuciak môže byt’ patrónom novinárov, ved’ má v sebe patron, DeNNíK N (Aug. 14, 2019, 11:24), https://dennikn.sk/1553675/kocner-v-threeme-kuciak-moze-byt-patronom-novinarov-ved-ma-v-sebe-patron/?ref= tema\#. On September 3, 2020, Marian Kočner and Alena Zsuzsová, who has also been charged with facilitating the murder, were acquitted by the first instance court, The Specialised Criminal Court. Appeal proceedings are pending before the Supreme Court of the Slovak Republic. See Marína Urbániková \& Lenka Haniková, Coping with the Murder: The Impact of Ján Kuciak's Assassination on Slovak Investigative Journalists, JOURNALISM PRAC. 1, 3-4 (2021).

(C) The Author(s) 2021. Published by Cambridge University Press on behalf of the German Law Journal. This is an Open Access article, distributed under the terms of the Creative Commons Attribution licence (https://creativecommons.org/licenses/by/4.0/), which permits unrestricted re-use, distribution, and reproduction in any medium, provided the original work is properly cited. 
communications showed how the businessman tried to interfere with the courts' decision-making processes while engaging in corruption with judges, prosecutors, and lawyers.

Police seized the phones of several judges, heads of courts, and the State Secretary of the Ministry of Justice to investigate the officials' potential contact with Kočner. Some of the judges were said to have exchanged thousands of messages with the businessman via the secured application. Transcripts of the conversations that appeared in the press suggested far-reaching manipulation of court cases in his favor, and communications published later, detailed instances of inappropriate communication between the judges and Marian Kočner. The judges, for the most part, denied any contact with the suspect. The State Secretary of the Ministry of Justice, Monika Jankovská, dismissed the evidence as invalid, claiming that the communications had been forged. When faced with political and public pressure, she eventually resigned from her office and resumed her former judge position at the Bratislava Regional Court. ${ }^{3}$ Dávid Lindtner, a judge who was the President of the Bratislava III District Court, was the first to confirm the authenticity of the published records. ${ }^{4}$

In the spring of 2020, thirteen judges were arrested by the Slovak police on charges of bribery, corruption, and abuse of power during the operation "Tempest" [Búrka]. ${ }^{5}$ Presidents and vice presidents of several Bratislava courts made up half of those charged, including the Supreme Court's Vice-Chairwoman, Jarmila Urbancová. The evidence establishing the judges' connections with Kočner was so overwhelming that the Constitutional Court approved the pre-trial detention of five of those arrested, while the rest were set to be prosecuted at large. ${ }^{6}$ The "Threema communication" scandal showed that Kočner had been interfering in the justice system for years. He had close contacts with judges at all levels of the courts-district, regional, Supreme, and Constitutional.

The summer and fall of 2020 saw operations "Gale" [Víchrica] ${ }^{7}$ and "Weeds" [Plevel], ${ }^{8}$ during which six more judges faced accusations. These investigations revealed that the judges had inappropriate relations with business leaders, politicians, and advocates, sometimes delivering decisions on request. In total, nineteen judges have been accused of corruption, bribery, and abuse of power. ${ }^{9}$

These events started a discussion on the reasons for these failures. The country has been democratic for more than 30 years, with the institution of the Judicial Council securing the autonomy of the judiciary since 2002, and with instruments of accountability and transparency in place. Although the public trust was extremely low even before Threema, and rumors about manipulating cases have been there for years, a scandal of such magnitude was shocking.

The public revelation of failures of judges led to the crisis of legitimacy. If democracy is the result of an institutionalized wager, if "everyone who supports it and wishes to belong to a

\footnotetext{
${ }^{3}$ Monica Tódová, Jankovská odstupuje z funkcie. Zásah polície považuje za svinstvo [Jankovská withdraws. Considers police intervention to filth], DENNík N (Sept. 3, 2019), https://dennikn.sk/1572323/jankovska-odstupuje-z-funkcie-zasah-policiepovazuje-za-svinstvo.

${ }^{4}$ David Lindtner, Judge Steps Down For Exchanging Messages With Kočner, The SlovaK Spectator (Oct. 21, 2019), https:// spectator.sme.sk/c/22241871/judge-stands-down-for-exchanging-messages-with-kocner.html.

${ }^{5}$ Adam Valček, Why did the police move against judges? One of them collaborated, THE SLOVAK SPECTATOR (Mar. 11, 2020), https://spectator.sme.sk/c/22355558/why-did-the-police-moved-against-judges-one-of-them-collaborated.html.

${ }^{6}$ Kočner's judges charged and detained, The SlovaK Spectator (Mar. 11, 2020), https://spectator.sme.sk/c/22355425/ kocners-judges-charged-and-detained.html.

${ }^{7}$ Most suspects facing corruption-related charges in the Operation Gale taken to custody, The SLOVAK SPECTATOR (Nov. 2, 2020), https://spectator.sme.sk/c/22524776/court-takes-most-suspects-from-operation-gale-into-custody.html.

${ }^{8}$ Police targeted judges in Žilina due to corruption, The SlovaK SPeCTATOR (Sept. 14, 2020), https://spectator.sme.sk/c/ 22488160/police-targeted-judges-in-zilina-due-to-corruption.html.

${ }^{9}$ Kočner's judges: Who has stepped down because of Threema so far? (overview), The Slovak Spectator (Nov. 5, 2019), https://spectator.sme.sk/c/22252665/kocner-judges-threema-resignations-overview-judiciary.html; Charges against judges show nobody is inviolable, THE SLOVAK SPECTATOR (Mar. 11, 2020), https://spectator.sme.sk/c/22356338/charges-againstjudges-show-nobody-is-inviolable.html.
} 
democratic political community assumes the risk that 'the wrong' people and policies are chosen as the result of fair elections," 10 then the rule of law rests on an institutionalized wager "that features independent justices and judges as the main protagonists." ${ }^{11}$ A system based on the rule of law ${ }^{12}$ must have strong confidence in the judiciary, which plays the primary role in the narrative of the rule of law.

In a liberal democracy based on the rule of law, the judiciary represents the structure responsible for restricting the sovereign's arbitrary will. Judges have the authority to, through qualified processes, curb political will rooted in the contemporary moment. Liberal democracy depends on the judges and the trust that the public holds in them. Therefore, the liberal democratic states adhere to the independence of the judiciary as the main trait of the system and one toward which it constantly aspires. The judiciary's independence establishes a structure of limitations and barriers that allow judges to decide on government administrator missteps. Members of the system presume that judges possess a high ethical standard and will not abuse their position.

Still, judges are human, with flaws and weaknesses, and they can fail in honoring the trust that the system puts in their hands. How, then, ought the system of power entrust itself not to be disappointed in its wager? Should there be a greater emphasis on accountability, or on integrity of the position of the judge? The Slovak judiciary will be presented in the following pages, starting with the problem it is facing today and searching for the roots of this problem in the events that have molded the Slovak judiciary.

In the early months of 2020, one could describe the judiciary situation in Slovakia as very different from that of Poland ${ }^{13}$ or Hungary. ${ }^{14}$ While Poland and Hungary were suffering from systemic attacks on the judiciary from political actors, Slovakia was facing low levels of confidence in the judiciary from the public, following Štefan Harabin's judicial leadership. Harabin subordinated the judiciary to his own needs mainly between 2006 and 2014, first from the Minister of Justice's position, and later as the President of the Supreme Court and Chair of the Judicial Council. ${ }^{15}$ Since last year, the situation has intensified, and now the Slovak judiciary faces not only record low levels of public trust, but also a need for crucial reform. Reformers seek to improve the quality of the judiciary and break the inappropriate alliances operating covertly in the regions

\footnotetext{
${ }^{10}$ Guillermo A. O’Donnell, Democracy, Law, and Comparative Politics, 36 StUd. Compar. InT'L Dev. 7, 17 (2001).

${ }^{11}$ Venelin I. Ganev, The Rule of Law as an Institutionalized Wager: Constitutions, Courts and Transformative Social Dynamics in Eastern Europe, 1 HaGue J. Rule L. 263, 267 (2009).

${ }^{12}$ The rule of law is used in the meaning of the ruler being bound by the law. There is no higher authority than the sovereign but the authority of law, to which both the sovereign and its representatives are accountable. Judges as the institutional guarantee serve "as a restriction on arbitrary power by the state, that no man, including officials, are above the law, and that the constitution is a result of judge-made law protecting individual rights.” AlBERT VENN DiceY, INTRODUCTION TO THE STUDY OF THE LAW OF THE CONSTITUTION 110-22 (8th ed. 1915).

${ }^{13}$ Extended comparative analysis of the attacks in James Moliterno \& Peter Čuroš, Recent Attacks On Judicial Independence: The Vulgar, The Systemic, And The Insidious, in this Special Issue. For Polish context see Fryderyk Zoll \& Leah Wortham, Judicial Independence and Accountability: Withstanding Political Stress in Poland, 42 FordHAM INT'L L.J. 875 (2019); Laurent Pech, Patryk Wachowiec \& Dariusz Mazur, Poland's Rule of Law Breakdown: A Five-year Assessment of EU's (in) Action, Hague J. Rule L. 1 (2021); Wojciech Sadurski, How Democracy Dies (in Poland): A Case Study of Anti-constitutional Populist Backsliding, Rev. Forumul Judecatorilor 104 (2018); Anna Śledzińska-Simon, The Rise and Fall of Judicial Self-Government in Poland: On Judicial Reform Reversing Democratic Transition, 19 GERMAN L. J. 1839 (2018).

${ }^{14}$ See Laurent Pech \& Kim Lane Scheppele, Illiberalism Within: Rule of Law Backsliding in the EU, 19 CAMBRIDGE Y.B. EUR. LEgAL STUD. 3 (2017); Tímea Drinóczi \& Agnieszka Bień-Kacala, Illiberal Constitutionalism: The Case of Hungary and Poland, 20 German L. J. 1140, 1142 (2019); Kriszta Kovács \& Kim Lane Scheppele, The Fragility of an Independent Judiciary: Lessons From Hungary and Poland-And the European Union, 51 Communist \& Post-Communist STUd. 189, 191 (2018).

${ }^{15}$ See DAVId Kosař, Perils OF JUdiCIAL SElF-GOVERNMENT IN TRANSITIONAL SOCIETIES: HOLdING THE LEAST ACCOUNTABLE BRANCH TO ACCOUNT (2016); Samuel Spáč, Katarína Šipulová \& Marína Urbániková, Capturing the Judiciary From Inside: The Story of Judicial Self-Governance in Slovakia, 19 GERMAN L. J. 1741 (2018); James E. Moliterno, Lucia Berdisová, Peter Čuroš \& Ján Mazúr, Independence Without Accountability: The Harmful Consequences of EU Policy Toward Central and Eastern European Entrants, 42 FORDHAM INT'L L. J. 481 (2018).
} 
outside of the Slovak capital. ${ }^{16}$ Many judges perceive this attempt for reform as an attack on the independence of the judiciary and as its political subordination. ${ }^{17}$ Much has happened since summer 2019 to lower the publics confidence in Slovak public administrators, and the judiciary played a contributing role in scandals that have uncovered corruption in Slovak politics, business, and law enforcement.

Extensive scholarship exists on the Czech and Slovak judiciaries' development in the aftermath of the Czechoslovak dissolution. ${ }^{18}$ My goals are, first, to highlight the underlying continuity that might reveal the roots of contemporary scandals in the judiciary in Slovakia. I will explain this continuity within the two main junctures in the history of the Slovak judiciary, which represent the starting point and following steps towards the recently uncovered crisis. Critical junctures refer to significant ruptures that cause discontinuities or interruptions that replace existing processes with various actions. ${ }^{19}$ In this case, discontinuities will be found in the events of the period after the Communist Party seized power in Czechoslovakia in February 1948 and the subordination of the judiciary during the tenure of Štefan Harabin as Minister of Justice and Supreme Court president from 2006 to 2014. These events are portrayed as critical junctures that shaped judges' habitus and factor into the judiciary's current crisis. These critical junctures do not necessarily overlap with political and economic junctures, for they are often consequences of events in the political and economic arenas. The junctures in the judiciary represent their own narratives and can be explained independently of political and economic narratives.

Second, this Article's argument does not directly connect the judiciary's dependency to the Communist legacy embodied in members of the judiciary who served before 1989 and are active today. Still, it presumes that the Communist heritage is a key to understanding the current situation. The explanation is not so straightforward that a few individuals are considered bearers of this heritage. Somewhat, the heritage of the past is hidden in informal practice-the habitus of the agents or members of the judiciary. This habitus may be unconscious yet defining for the behavior of the agents.

Third, this Article does not aim to compare the situation and actions of the members of the judiciary in the period of state socialism with the situation and actions today. The systems are so crudely different that they cannot be compared, and the role of the judiciary within institutions was also fundamentally different. The Article aims to identify which continuities of the judicial habitus are apparent in the current judiciary. To demonstrate changes in the position of the judiciary, this Article will present an argument of the development of the judiciary from an

\footnotetext{
${ }^{16}$ Ministerka spravodlivosti predstavila novú súdnu mapu, Ministerstvo SPRAVOdLIVOSTI SLOVENSKej RepUbLIKY (Nov. 23, 2020), https://www.justice.gov.sk/Stranky/aktualitadetail.aspx?announcementID=3050.

${ }^{17}$ Súdna mapa inak, PRÁVNe LISTY (Dec. 2, 2020), http://www.pravnelisty.sk/clanky/a908-sudna-mapa-inak?fbclid= IwAR1tseWu9bemvmMi20Yx3abscWGil1CIMjRNOyGYJg5XPBTNustEh-gWpqs.

${ }^{18}$ David Kosař, Politics of Judicial Independence and Judicial Accountability in Czechia: Bargaining in the Shadow of the Law between Court Presidents and the Ministry of Justice, 13 Eur. Const. L. Rev. 96 (2017); Kosař, supra note 15; David Kosař, Jiří Baroš \& Pavel Dufek, The Twin Challenges to Separation of Powers in Central Europe: Technocratic Governance and Populism, 15 Eur. Const. L. Rev. 427 (2019); David Kosař \& Samuel Spáč, Conceptualization(s) of Judicial Independence and Judicial Accountability by the European Network of Councils for the Judiciary: Two Steps Forward, One Step Back, 9 INT'L J. FOR CT. Admin. 37 (2018); David Kosař \& Samuel Spáč, Post-communist Chief Justices in Slovakia: From Transmission Belts to Semiautonomous Actors?, 13 Hague J. Rule L. 107 (2021); Samuel Spáč, Recruiting European Judges in the Age of Judicial SelfGovernment, 19 German L. J. 2077 (2018); Samuel Spáč, Katarína Šipulová \& Marína Urbániková, Capturing the Judiciary from Inside: The Story of Judicial Self-Governance in Slovakia, 19 GERMAN L. J. 1741 (2018); Katedra POLITOLÓGIE FIF UK, ERIK LÁŠTIC, SAMUEL SPÁČ, NEdOTKNUTELNí?, UK, 2017 (Feb. 8, 2018), https://www.politologiauk.sk/nove/2018/2/8/erik-lticsamuel-sp-nedotknuten-uk-2017; Michal Bobek, The Fortress of Judicial Independence and the Mental Transitions of the Central European Judiciaries, 14 Eur. Pub. L. 99 (2008); Michal Bobek \& David Kosař, Global Solutions, Local Damages: A Critical Study in Judicial councils in Central and Eastern Europe, 15 GERMAN L. J. 1257 (2014); ZDENĚK KÜHN, THE JUdiCIARY IN CENTRAL AND EASTERN EUROPE: MECHANICAL JURISPRUDENCE IN TRANSFORMATION? (2011).

${ }^{19}$ Giovanni Capoccia \& R. Daniel Kelemen, The Study of Critical Junctures: Theory, Narrative, and Counterfactuals in Historical Institutionalism, 59 WORLD POL. 341, 348 (2007).
} 
instrument of the governing party in maintaining a homogenous and subordinated society to the current situation of the Slovak judiciary, defined as a crisis of mental independence resulting in inappropriate behavior and corruption. To understand the current scandals of Slovak judges, this Article aims to demonstrate the process of the shift in judicial habitus from a subservient, oppressed instrument of power to a structurally independent yet mentally dependent branch of state power. ${ }^{20}$ This Article is novel in its approach of analyzing how the structural changes in the judiciary-both after 1948 and after 1989-have influenced the informal institutions within the judiciary, including the self-perception and habitus of the judges.

This Article begins Section B with Slovakia's main focus on structural independence after accession to the EU. The framework for the independence of the Slovak judiciary is summarized. Section C deals with the trope of the panopticon ${ }^{21}$ and concept of habitus, ${ }^{22}$ and intends to explain the continual processes at play in the current situation. Section $\mathrm{D}$ deals with the first critical juncture of the Slovak judiciary and the way that the Czechoslovak judiciary ceded its independence as it was transformed into a repressive and ideological instrument of the Communist Party of Czechoslovakia. Section E follows with the second juncture during Harabin's leadership in the presidency of the Supreme Court and Judicial Council. Section F offers a summary of the analysis.

\section{B. Focusing on Institutional Structure and Forgetting the Judicial Mentality}

The fact that so many judges served private demands and commands was unexpected because the Slovak judiciary's institutional framework is based on, and shows adherence to, all the significant international recommendations designed to safeguard judicial independence. The critical powers in the management of judicial affairs are in the hands of a balanced and autonomous Judicial Council of the Slovak Republic (Judicial Council), and the powers of other branches are limited. Political pressure on the courts is formally hindered.

The judiciary's independence is reinforced at all formal stages of a judge's career: Selection, appointment, relocation, promotion and advancement, training, performance appraisal, and disciplinary responsibility. These activities are all conducted by the Judicial Council, overseen by bodies created by the Judicial Council, ${ }^{23}$ or in hands of the court presidents. The Slovak legislature has continuously adhered to the requirements of the European Union (EU) and the Council of Europe (COE) ${ }^{24}$ The concept of judicial independence has been the nucleus of the Slovak discourse.

Many criteria for fostering judicial independence have been introduced in recent years by various international institutions. First, the Council of Europe's consultative organization known as the Consultative Council of European Judges (CCJE) recognizes statutory, functional, and financial bases. ${ }^{25}$ Another institution, the European Commission for the Efficiency of Justice (CEPEJ), discusses independence based on internal and external independence criteria. ${ }^{26}$ Still another

\footnotetext{
${ }^{20} \mathrm{Mental}$ dependency referring to a lack of personal courage that insulates the judge from inappropriate influence.

${ }^{21}$ Circular building, where power is executed through hierarchical observation, normalization of judgment and examination.

${ }^{22}$ Patterns of behavior observable within a certain community, that mirror the prevailing social and cultural conditions of the community.

${ }^{23}$ Art. 141(a) of the Constitution concerning the Judicial Council of the Slovak Republic, No. 460/1992 Coll., inserted by the constitutional act No. 90/2001 Coll.-Act No. 185/2002 Coll. on the Judicial Council of the Slovak Republic.

${ }^{24}$ According to European Network of Councils of the Judiciary (ENCJ) report 2019-2020, Report IAQ 2019-2020, at 41, on the level of sixty percent-this indicator is interesting to compare to year 2017, when ENCJ evaluated legal basis of judicial Independence on eighty-four percent-and organizational autonomy was guaranteed on almost seventy-eight percent. eightytwo percent in 2017, at 117 .

${ }^{25}$ Magna Carta of Judges, Consultative CounCil of European Judges [CCJE], (Nov. 17, 2010), https://rm.coe.int/ $16807482 \mathrm{c} 6$.

${ }^{26} J$ udges: Independence, Efficiency and Responsibilities. Recommendation CM/Rec(2010)12 and Explanatory Memorandum, COUNCIL OF EUROPE, (2011), https://rm.coe.int/16807096c1.
} 
classification system for independence is outlined by the European Network of Councils of the Judiciary (ENCJ), the consultative institution of the European Commission. This classification is based on the objective independence of the entire judiciary, including the objective independence of the individual judges and subjective independence of the judiciary. ${ }^{27}$

Looking more closely at the ENCJ's standards, ${ }^{28}$ one can see that Slovakia has formally implemented most of its requirements. For example, the objective independence of the judiciary was formally secured with the following enacted measures: The legal basis of independence, ${ }^{29}$ assurances that the law binds judges, ${ }^{30}$ methods for the determination of judges' salaries, ${ }^{31}$, mechanisms for the adjustment of judges' salaries, ${ }^{32}$ and guarantees of the involvement of judges in reforming the judiciary. ${ }^{33}$ Moreover, there is the organizational autonomy of the judiciarythe legal basis and real existence of an institution for the administration of the judiciary-the Judicial Council. ${ }^{34}$ Slovakia has demonstrated compliance with guidelines from the COE and the EU on judges influence on personal representation in the institution. ${ }^{35}$ Further, the objective independence of the judge is formally secured through human resource decisions regarding their selection, ${ }^{36}$ appointment, ${ }^{37}$ promotion, and dismissal. ${ }^{38}$ There are also rules regarding the non-transferability of judges without their consent, ${ }^{39}$ except in the situation that the transfer emerges as a sanction for a breach of disciplinary rules. ${ }^{40}$ This also includes internal independence from the influence of superior courts or court management. ${ }^{41}$

Even though the regulatory framework for securing judicial independence has been formally fulfilled, the perceptions of the judiciary held by Slovak citizens have not followed with increased trust. Slovakia has implemented the above-mentioned requirements, and their success indicators are measured regularly by ENCJ. ${ }^{42}$ Public perceptions of independence and inappropriate interference are also measured regularly. Regarding the subjective independence of the judiciary, the Slovak judiciary has continually ranked worst or second-worst among European countries in major surveys measuring public trust in the judiciary, the perceived independence of judges, and other aspects integral to the functioning of a fair judiciary in Europe. The justice system, particularly the judiciary, has faced continually low levels of trust from the public, as reflected in these surveys. According to the 2020 Eurobarometer survey results, sixty-four percent of the public ranked the justice system's independence as bad, while twenty-six percent ranked it

27 Independence, Accountability and Quality of the Judiciary, EUROPEAN NETWORK OF COUNCILS OF THE JUDICIARY [ENCJ], https://www.encj.eu/images/stories/pdf/workinggroups/independence/encj_report_ia_ga_adopted_ga_13_6.pdf (last visited July 1, 2018).

${ }^{28}$ See the Special Issue on Measuring Judicial Independence and Accountability, Frans Van Dijk \& Geoffrey Vos, A Method for Assessment of the Independence and Accountability of the Judiciary, 9 INT'L J. CT. ADMIN. 1 (2018), and responding papers.

${ }^{29}$ Art. 141 Slovak Const. no. 460/1992 Coll.

${ }^{30}$ Art. 2 of the Law on Judges no. 385/2000 Coll.

${ }^{31}$ Law on remuneration of judges no. 670/2002 CoLL.

${ }^{32}$ Id. See also judgment of 11 December 2011, PL. Ús 99/2011 secured inviolability of the judge's salaries.

${ }^{33}$ Art. 4 of the Act on Judicial Council 185/2002 Coll.

${ }^{34}$ Act on Judicial Council 185/2002 Coll.

${ }^{35}$ Art. 10 of the Act on Judicial Council 185/2002 Coll.

${ }^{36}$ Art. 28 of the Law on Judges 385/2000 Coll.

${ }^{37}$ Art. 5 of the Law on Judges 385/2000 Coll.

${ }^{38}$ Art. 15 and 16 of the Law on Judges 385/2000 Coll.

${ }^{39}$ Art. 14 of the Law on Judges 385/2000 Coll.

${ }^{40}$ Art. 117 of the Law on Judges 385/2000 Coll.

${ }^{41}$ Art. 2 of the Law on Judges 385/2000 Coll.

${ }^{42}$ See e.g., Councils for Judiciary Report 2010-2011, ENCJ Report 2013-2014 Independence and Accountability of the Judiciary - ENCJ Report 2012-2013 Distillation of ENCJ Guidelines, Recommendations and Principles - ENCJ Report 2011-2012 Judicial Reform in Europe, ENCJ Report on Independence, Accountability and Quality of the Judiciary 2016-2017, etc., on https://www.encj.eu. 
as good. ${ }^{43}$ For comparison, in 2017, fifty-nine percent rated Slovakia's judicial system as untrustworthy, while twenty-five percent of people in Slovakia tended to trust it. ${ }^{44}$ In a survey on corruption, fifty-two percent of the sample thought bribery and the abuse of power for personal gain were happening in the courts. ${ }^{45}$

Perhaps more telling are the surveys' results on how judges and legal professionals perceive the system in which they work. Judges' perception of the guarantee of independence was rated above eighty percent in both $2019^{46}$ and $2020 .{ }^{47}$ In the report by the ENCJ on independence in 2018-2019, Slovak judges perceived their independence as a nine on a scale of ten ${ }^{48}$ while "that the (net) largest percentage of the judges that have experienced a big improvement of independence are those that have started twenty-five years ago." 49 The perceived independence of the judiciary among judges within the system is consistently high. ${ }^{50}$

By contrast, only fifty-four percent of lawyers perceive the judiciary as independent. ${ }^{51}$ Slovak lawyers perceive the most inappropriate source of pressure to be parties and their lawyers, with the government in second place and other judges - including an association of judges-in third place. ${ }^{52}$ Meanwhile, forty percent of Slovak judges believe that judges are inappropriately influenced by the media. Based on the results, Slovak judges do not consider their independence to be threatened by the executive and legislative powers, nor by the court management. ${ }^{53}$

Almost sixty percent of the Slovak lawyers in the survey think that in the last two years, judges have been under inappropriate pressure to make a specific decision in a case. ${ }^{54}$ More than half of the surveyed lawyers are convinced that in the same period, individual judges accepted bribes or engaged in other forms of corruption as an inducement to decide cases in a particular way. ${ }^{55}$

\footnotetext{
${ }^{43}$ Eurobarometer: Public Opinion in the European Union, EuROPEAN COMMIssion, https://ec.europa.eu/commfrontoffice/ publicopinion/index.cfm/Survey/getSurveyDetail/search/justice/surveyKy/2258 (last visited Feb. 4, 2021).

${ }^{44}$ Eurobarometer: Public Opinion in the European Union, EUROPEAN COMMISsION, https://ec.europa.eu/commfrontoffice/ publicopinion/index.cfm/Survey/getSurveyDetail/yearFrom/1974/yearTo/2017/surveyKy/2148 (last visited Feb. 4, 2021). The long term pattern of low trust in institutions is also visible in Eurobarometer 2013, while across the EU, fifty-three percent of the population tend to trust to the national justice system and forty-three percent tend not to. In Slovakia the trust was twentyfive percent and the distrust sixty-six percent; nine percent did not know whether they trusted or not.

${ }^{45}$ Eurobarometer: Public Opinion in the European Union, EUROPEAN COMMISsION, https://ec.europa.eu/commfrontoffice/ publicopinion/index.cfm/Survey/getSurveyDetail/yearFrom/1974/yearTo/2017/surveyKy/2176 (last visited Feb. 4, 2021).

${ }^{46}$ Independence and Accountability of the Judiciary, ENCJ Survey on the independence of Judges 2019, EUROPEAN NETWORK OF COUNCILS FOR THE JUDICIARY (ENCJ), (2019), https://pgwrk-websitemedia.s3.eu-west-1.amazonaws.com/production/ pwk-web-encj2017-p/Reports/Data\%20ENCJ\%202019\%20Survey\%20on\%20the\%20Independence\%20of\%20judges.pdf.

${ }^{47}$ Independence, Accountability and Quality of the Judiciary, ENCJ Report 2019-2020 (2020), EUROPEAN NETWORK OF COUNCILS FOR THE JUDICIARY (ENCJ), https://pgwrk-websitemedia.s3.eu-west-1.amazonaws.com/production/pwk-webencj2017-p/Reports/ENCJ\%20report\%20IAQ\%202019-2020\%20adopted\%20GA\%202020.pdf.

${ }^{48}$ Independence, Accountability and Quality of the Judiciary, ENCJ Report 2018-2019, at 34 (2019), EUROPEAN NETWORK OF COUNCILS FOR THE JUDICIARY (ENCJ), https://pgwrk-websitemedia.s3.eu-west-1.amazonaws.com/production/pwk-webencj2017-p/GA\%2019/ENCJ\%20IAQ\%20report\%202018-2019\%20adopted\%207\%20June\%202019\%20final-july.pdf.

${ }^{49} I d$. at 35 .

${ }^{50}$ More detailed numbers show that inappropriate pressure from other branches of state power is not common. More than ninety-five percent of the judges disagree that during last two years they were under inappropriate pressure to take a decision in a case or part of a case in a specific way. $I d$. at 36.

${ }^{51}$ Independence and Accountability of the Judiciary, ENCJ/CCBE Survey among lawyers on the independence of Judges 2018-2019, at 18, European NeTwOrK OF COUNCILS FOR THE JUdiCIARY (ENCJ), https://pgwrk-websitemedia.s3.eu-west1.amazonaws.com/production/pwk-web-encj2017-p/Reports/ENCJ\%20Survey\%20on\%20Independence\%20Accountability\% 20of\%20the\%20Judiciary\%20among\%20lawyers\%20\%202019.pdf.

${ }^{52} I d$. For comparison, parties and their lawyers usual number one choice of Czech Republic, Cyprus, and Lithuania. In the region, for Poland is the source of the inappropriate pressure the Government and in Hungary Government together with Court Management.

${ }^{53}$ EuropeAn NETWORK OF COUNCILS FOR THE JUdiCIARY (ENCJ), supra note 46, at 41.

${ }^{54}$ EUROPEAN NETWORK OF COUNCILS FOR THE JUdiCIARY (ENCJ), supra note 48, at. 62, figure 49.

${ }^{55}$ European NeTWORK OF COUNCILS FOR THE JUdiCIARY (ENCJ), supra note 51, at 19. For comparison, in Poland, it is only thirteen percent, in Hungary fifteen percent, and in Czech Republic forty-five percent.
} 
Almost forty percent of lawyers believe that the courts' management has exerted pressure on judges to decide individual cases in a particular way during the last two years. ${ }^{56}$ Trust in judges selection process is still low, as more than sixty percent of lawyers believe that judges have entered the judiciary not solely on the basis of their ability and experience in the past two years. ${ }^{57}$ According to the lawyers survey, judicial corruption is a huge problem;seventy-five percent of lawyers disagree with the statement that the judicial authorities effectively address judicial corruption. ${ }^{58}$

Based on the ENCJ survey results, members of the legal profession doubt the independence of the judges within the judiciary, mainly due to the interference of parties and their lawyers. The entire problem of corruption is addressed very ineffectively by the judicial authorities. In sum, those outside the judiciary-both lawyers and the public - consider the judiciary to not be fully independent. Their answers do not indicate that the legal framework could be responsible for allowing interference in judicial decision-making but that the breach of rules is the issue.

In 2018 the advisory organization by the Council of Europe, CCJE, decided to address this problem by giving a recommendation, particularly for jurisdictions, that implemented safeguards for independence, but they did not move forward toward their goal of improving public trust. Later that same year, the Council released Opinion 21 on corruption. ${ }^{59}$

The recommendation included all the necessary points, but its solution mainly called for furthering the development of independence. ${ }^{60}$ The opinion exaggerates a requirement for the deterrence of corruption, and it recommends that the judiciary is funded appropriately, and that adequate salaries and pensions allow judges to not fear for their financial situation. Furthermore, the opinion declares that judicial standards should not be kept secret, and regulations, codes of ethics, and guidelines for judicial conduct should be easily accessible by judges. These solutions do not seem to explain the occurrence of the judges failures in Slovakia. The salaries of the Slovak judges are above average ${ }^{61}$ compared to other countries in the region, and the code of ethics and the rules on expected behavior by judges ${ }^{62}$ are public and accessible.

The establishment of the formal instruments of the separation of power was a priority, while an understanding of students and judges on the informal rules of professional behavior was lacking. The judges simply adapted to the standards of the institution once they started working. The problem of the Slovak judiciary seems to be in the failure of maintaining mental independence, both on

\footnotetext{
${ }^{56}$ For comparison, it was thirty percent in Czech Republic, thirty-two percent in Poland, and almost sixty percent in Hungary.

${ }^{57}$ European NeTwOrk OF COUNCILS FOR THE JUdiCIARY (ENCJ), supra note 51, at 23.

${ }^{58}$ In comparison to the Czech Republic it is forty percent, in Hungary forty-five percent, and in Poland less than thirty percent.

${ }^{59}$ As the Opinion 21 declares-corruption must be considered in broader sense-as every conduct of the judge that is dishonest, fraudulent, or unethical in order to acquire personal benefit or benefit for third parties. Corrupting conduct can be invoked by undue influence from outside the judiciary as well as from within the court system. CONSULTATIVE Council of European Judges (CCJE), CCJE OpInION No. 21 (Nov. 9, 2018), https://www.coe.int/en/web/ccje/ccjeopinions-and-magna-carta.

${ }^{60}$ Important for avoiding corruption within the judiciary is providing the necessary institutional, infrastructural, and other organizational safeguards, as independence can be maintained only when secured by institutional framework. The most effective is legislative confirmation of such conditions for independence. See CCJE OPINION No. 21, supra note 59.

${ }^{61}$ Samuel Spáč, Sudcovia A Sudcovské Kariéry v Post-Tranzitnej Spoločnosti, in NedotKnutelní? 5, 22 (Erik Láštic, Samuel Spáć, eds., 2017), https://static1.squarespace.com/static/55fd17f3e4b08422c88865c9/t/5a54d0a0e2c4836a1c48c73e/ 1515507881083/2017_nedotknutelni_Lastic-Spac.pdf. The average salary of the judge in Slovakia is 2.9 times higher than the average income in national economy. In this regard, only judges in Estonia, Romania, Bulgaria, Cyprus, and Malta have higher incomes than Slovak judges. The situation of remuneration of judges is stable. In 2011, Lukasz Bojarski and Werner Stemker Koster reported that the average salary of the judge is 3 times the average salary in the country for a young judge and 4.2 times of a judge at the end of the career. See Lukasz Bojarski \& Werner Stemker Koster, The Slovak Judiciary: Its Current State and Challenges, BRATISLAVA: OPEN SOC'y Found. (2012).

${ }^{62}$ SÚdNA RADA SlOvENSKej REPUBliky, Zásady sudcovskej etiky [Standards On Judicial Ethics, Judicial Council of the Slovak Republic], https://www.sudnarada.gov.sk/zasady-sudcovskej-etiky/ (last visited Feb. 4, 2021).
} 
the part of the judges to not surrender to pressure, as well as on the part of influential players, like politicians, superiors, and business leaders, not to interfere and put pressure on judges. John Ferejohn writes that judicial independence is less a consequence of institutional design and more, "a consequence of self-restraint by powerful groups." ${ }^{33}$ Moreover, Michal Bobek claims, "[t]he independence of the judiciary is, however, not about the institutions, but about the judicial mentality and self-image." ${ }^{4}$ He writes further, "[i]t does not matter who the powerful groups are, whether political branches or judges, there will always be a certain capacity to influence the judiciary and its composition." ${ }^{6}$ Though, what should be done, if powerful groups do not feel restricted and judges are immersed in their everyday life of informal practice that does not seem controversial to them?

In such a situation, focusing on the institutional structure of the judiciary may be a weak method of determining independence, for "to check mechanically whether or not new laws are passed or whether a new judicial council is put in place is incomparably easier than to engage in complex assessment of judicial self-image, mentality, and ideology." "66 Samuel Spáč concludes that with the existence of a normative framework in place in Slovakia:

The Slovak experience hence shows that the transfer of powers regarding the professional careers of judges from politicians to judges themselves is not a guarantee of judicial independence. Judges, just as any other actor in power, may be willing to use this competence to influence the outcomes of judicial proceedings. ${ }^{67}$

\section{Informal Institutions-Habitus in Panopticon}

Various works relate the problem of non-compliance of formal institutions, seeking the rule of law, with persisting practice furthering personal interest. ${ }^{68}$ Michal Bobek explained it as institutional mimicking, when "new institutions are created, but the values and patterns of behaviour which are necessary for the institution to function properly do not come with it." 69 Informal institutions might be central to resolving the issue of institutional changes not yielding a desired outcome. Institutions are enduring features of political and social life that structure behavior and cannot be changed easily or instantly. They consist of the formal "rules of the game" and their enforcement along with the informal practices and beliefs, which are often less visible or even unnoticed by actors inside and outside of those institutions. ${ }^{70}$

\footnotetext{
${ }^{63}$ John Ferejohn, Independent Judges, Dependent Judiciary: Explaining Judicial Independence, 72 S. CAL. L. REV. 353,375 (1999).

${ }^{64}$ Bobek, supra note 18 , at 99.

${ }^{65}$ Samuel Spáč, Informal Judicial Networks and Judicial Independence in the Aftermath of Ján Kuciak's Murder, V4 HuM. RTS. REV. 40, 41 (2020).

${ }^{66}$ Bobek, supra note 18 , at 100 .

${ }^{67}$ Spáč, supra note 65, at 42. See Pavol Zilincik, Etika v sobě, kodex ve skř́ni, soudci ve vazbě, důvěra. 11-12 SouDCE, 15 (2020) ("In Slovakia there is, at least on paper, almost perfect institutional framework for [independence of] judiciary.")

${ }^{68}$ GRETCHEN HELMKE \& STEVEN LEVITSKY, INFORMAL INSTITUTIONS AND DEMOCRACY: LESSONS FROM LATIN AMERICA (2006); Santiago Basabe-Serrano, Informal Institutions and Judicial Independence in Paraguay, 1954-2011, 37 L. \& POL'Y 350, 353 (2015); Björn Dressel, Raul Sanchez-Urribarri \& Alexander Stroh-Steckelberg, Courts and Informal Networks: Towards a Relational Perspective on Judicial Politics Outside Western Democracies, 39 Int'L Pol. SCI. Rev. 573 (2018); Åse B. Grødeland \& Aadne Aasland, Informality and Informal Practices in East Central and South East Europe: Complex Europe (2007); Anna Grzymala-Busse, The Best Laid Plans: The Impact of Informal Rules on Formal Institutions in Transitional Regimes, 45 STUd. CoMPaR. INT'L DeV. 311, 313 (2010).

${ }^{69}$ Bobek, supra note 18 , at 107.

${ }^{70}$ James Mahoney \& KathleEn Thelen, Explaining institutional Change: Ambiguity, AgenCy, AND POWER 4 (2009).
} 
Habitus is a part of an informal institution of shared rules and traditions within a group or community. These informal rules and traditions work outside officially sanctioned channels. They are distinct from formal institutions, which are "rules and procedures that are created, communicated, and enforced through channels widely accepted as official." ${ }^{\text {"1 }}$ Informal institutions may also appear as unofficial interpretations of formal rules. Such informal practices that differ from the aim of formal institutions can complement, support or contradict the formal rule. ${ }^{72}$ When contradicting the formal rule, they tend toward corruption, especially in communities where disregard for formal rules is strong. ${ }^{73}$ The problem of informal practices contradicting formal rules is more emergent in countries where the courts face low trust or negative perception by the public. ${ }^{74}$ In such countries, informal practices in the judiciary occur in the form of co-optation ${ }^{75}$ and clientelism, ${ }^{76}$ which can lead to sophisticated networks of judicial corruption ${ }^{77}$ and the decay of judicial independence. ${ }^{78}$

Over time these informal institutions become stronger and take over the rules of judicial life. If deeply rooted, these informal institutions can hinder change even after the formal rules are adapted; "when judicial independence has been low in a country due to the presence of co-optation, clientelism, and corruption, it is highly unlikely that reforms will immediately improve the degree of judicial independence." ${ }^{79}$ A habitus of informal loyalties leads to informal networks ${ }^{80}$ from which political actors and involved judges can benefit.

\section{Panopticon}

The process of judiciary development in Czechoslovakia, and later Slovakia, can help explain why the Slovak judiciary is facing its current situation. This process will be explained through two critical junctures that formed the habitus of the Slovak judges over the past seventy years. The argument will be presented via the trope of the panopticon, a concept for a new type of prison put forth by Jeremy Bentham. The panopticon effectively uses disciplinary power to control the behavior of inmates.

\footnotetext{
${ }^{71}$ Gretchen Helmke \& STEVen LeVitsky, Informal institutions and DEMOCRACY: LeSSONS FROM LATIN AmERICA 5 (John Hopkins University Press ed., 2006).

${ }^{72}$ Anna Grzymala-Busse, The Best Laid Plans: The Impact of Informal Rules on Formal Institutions in Transitional Regimes, 45 Stud. Compar. Int'L Dev. 311, 313 (2010).

${ }^{73}$ Åse B. Grødeland \& Aadne Aasland, Informality and Informal Practices in East Central and South EASt EURope: COMPLEX Europe (2007).

${ }^{74}$ Åse B. Grødeland \& Aadne Aasland, Elite Perceptions of the Judiciary in East Central and South East Europe, 21 EUR. REV. 70 (2013).

${ }^{75}$ The process of adding members to an elite group at the discretion of members of the body, usually to manage opposition and so maintain the stability of the group.

${ }^{76}$ As mutually beneficial, particularistic, and informal relationships between patrons and clients that inhibit equal access to public sources and markets. See Luis Roniger, Political Clientelism, Democracy, and Market Economy, ComP. PoL. 353, 353 (2004).

${ }^{77}$ The use of public authority for the private benefit of court personnel when this undermines the rules and procedures to be applied in the provision of court services. See Edgardo Buscaglia, An Analysis of Judicial Corruption and its Causes: An Objective Governing-Based Approach, 21 INT'L REv. L. \& ECON. 233, 235 (2001).

${ }^{78}$ Santiago Basabe-Serrano, Informal Institutions and Judicial Independence in Paraguay, 1954-2011, 37 LAW \& POL. 350, 353 (2015); Björn Dressel, Raul Sanchez-Urribarri \& Alexander Stroh-Steckelberg, Courts and Informal Networks: Towards a Relational Perspective on Judicial Politics Outside Western Democracies, 39 INT'L POL. SCI. Rev. 573 (2018). If the breakthrough in untying hands for police and prosecution office to investigate judges, as in Slovakia happened, it may reflect a breakdown in agreements to cooperate between politicians and judges. See Mariana Llanos, Cordula Tibi Weber, Charlotte Heyl \& Alexander Stroh, Informal Interference in the Judiciary in New Democracies: A Comparison of Six African and Latin American Cases, 23 DEMOCRATIZATION 1236 (2016).

${ }^{79}$ Basabe-Serrano, supra note 78 , at 353.

${ }^{80}$ Björn Dressel, Raul Sanchez-Urribarri \& Alexander Stroh-Steckelberg, Courts and Informal Networks: Towards a Relational Perspective on Judicial Politics Outside Western Democracies, 39 INT'L PoL. SCI. Rev. 573 (2018).
} 
The panopticon is an invention of the early Enlightenment era, a period defined by changes in society's power structures. Disciplinary power is based on hierarchical observation and the normalization of judgment and examination. It replaced a sovereign power, reliant on corporal punishment and the spectacle of execution. The panopticon gives us an idea of how power can work in the disciplinary age:

The building is circular. The apartments of the prisoners occupy the circumference. You may call them, if you please, the cells. These cells are divided from one another, and the prisoners by that means secluded from all communication with each other, by partitions in the form of radii issuing from the circumference towards the centre, and extending as many feet as shall be thought necessary to form the largest dimension of the cell. The apartment of the inspector occupies the centre; you may call it if you please the inspector's lodge. ${ }^{81}$

The structure is designed so that from a central point, one can observe all the prisoners' behavior. Every prisoner is separated in his cell and cannot see whether the inspector observing from the central point is watching him. The prisoner needs to behave as if the inspector is always watching. The prisoner does not break the rules, and it does not make sense for him to consider breaking the rules, as it would be irrational and ineffective. ${ }^{82}$ The inmate's well-being depends on the inspector's commands, not on any ethical standard of behavior.

The subordination of the judiciary by the political power after the coup of the Communist Party of Czechoslovakia in February 1948 resembles the process of inmates becoming subordinate to the inspector. The bureaucratic structure of the judiciary, which was inherited from the Austro-Hungarian Empire, made the Czechoslovak judiciary likely to become subservient within the hierarchical order of the state. The predominant judicial culture and self-perception tended to be one of a well-paid civil servant when the Austrian bureaucratic spirit merged with the rule of the working class, "phone justice," and the Communist doctrine of unity of the state power. ${ }^{83}$ The administration of the courts was a two-layered system: the central administrative body was the ministry, while local administration was served by the presidents and vice presidents of courts. ${ }^{84}$

The inspector can interfere with any activity of the inmates any time the inspector wishes to do so. The inmate must think carefully before committing any action against the inspector's wishes, as the inmate can expect to be caught and punished when not complying with the inspector's will. Over time, the inmates comply without resistance and the need for force. The Czechoslovak judiciary became subservient and obedient to the political power of the Party, which stood in the inspector's lodge, ready to interfere at any moment it wished.

After 1989, the inspector-the Party's political control-slowly abandoned the panopticon. After the dissolution of Czechoslovakia in 1993, Slovakia used the administration of the courts centralized by the Ministry of Justice and the courts' presidents. By 2001, when the Judicial Council's body was introduced, the "political inspector" had slowly faded away, even more after $2011 .{ }^{85}$

At this moment in the panopticon, relieved of its political inspector, the inmates know that they are no longer being watched and that the panopticon belongs to them. Yet, because the judiciary was rebuilt as a panopticon at the beginning of the 1950s and was not rebuilt afterward, it has not changed its structure simply because the original inspector is gone. The panopticon walls were not

\footnotetext{
${ }^{81}$ Jeremy Bentham, Panopticon: OR the InSPeCtion-House 5 (2012), https://www.ics.uci.edu/ djp3/classes/2012_09_ INF241/papers/PANOPTICON.pdf.

${ }^{82}$ Michel Foucault, Discipline \& Punish: The Birth Of The Prison 204 (A. Sheridan Trans., 1995).

${ }^{83}$ Michal, supra note 18 , at 107.

${ }^{84}$ Michal Bobek, The Administration of Courts in the Czech Republic: In Search of a Constitutional Balance, 16 EUR. PUB. L. 253 (2010).

${ }^{85}$ Samuel SpaČ, Matej ŠimalČik \& Gabriel Šipoš, Let's Judge The Judges: How Slovakia Opened ITS JudiCiary to UnPreCedented Public Control 3 (2018), https://transparency.sk/wp-content/uploads/2018/03/Impact-Study_pdf_final. pdf.
} 
torn down, and the lodge still stands. The inmates have not lost the habitus of subservience to the power that stands in the inspector's lodge. Ultimately, after the Communist Party, after 1989, and later Minister of Justice, after 2001, left the post of inspector, the lodge was occupied by the power within the judiciary. A group of elites within the judiciary became the new inspector, who seemed to serve the highest bidder. The rest of the judiciary members could either obey the reign of the new inspector or defy and face the punishment.

The judiciary ceased to be a tool in the hands of the political power, but became an important player in the new political system in the powerful judicial elite's hands that succeeded the inspector. In the new democratic system, the judiciary was meant to be a wager on democracy and the rule of law, not a weapon in any hands. With the habitus of subserviency to a stronger player, judges may tend to support anyone who furthers their interests, such as by guaranteeing higher salaries, less accountability, and more freedom, behind which corruption can more easily exist without detection. The judiciary replaced its master with a new one. This shows that the key change is not the formal regulations that established independence but the change in informal practice, judges attitudes of courage, seen in a commitment to independence and accountability.

\section{Habitus of the Judiciary}

The concept of habitus offers an answer to how it is that even through changes in personnel, legislation, and the position of the institution of the judiciary, the pattern of judicial behavior still tends toward subservience. Why do the patterns of behavior persist within the informal institution of the judiciary, even after the agents and normative framework have changed?

Habitus refers to patterns of behavior observable within a certain community. These patterns mirror the prevailing social and cultural conditions of the community. ${ }^{86}$ As Pierre Bourdieu explains, habitus is the underlying structure of social life, the way we approach a range of objective possibilities ${ }^{87}$ with knowledge about ourselves, "[ $\left.t\right]$ he habitus is the source of these series of moves which are objectively organized as strategies without being the product of a genuine strategic intention-which would presuppose at least that they are perceived as one strategy among other possible strategies." 88

The members of a group internalize a pattern of behavior and reproduce it through their actions. Habitus instills the values and notions of correct ways of action in its subjects. Although all social phenomena are constructed by human will, habitus is perceived by the group as natural, in the sense of pre-cultural.

Institutions and the behavioral elements of habitus form the individual's actions and view toward the world. Because of institutions and habitus, the individual becomes, on the one hand, an agent — defined by agency and will — and on the other hand, a subject, subservient to the power structures of the institutions, limited by habitus in scope and way of action. As subjects repeat the habitus, they recreate and strengthen it, unaware that they are contributing to its legitimacy.

As Bourdieu claims, "[i]n each of us, in varying proportions, there is part of yesterday's man; it is yesterday's man who inevitably predominates in us since the present amounts to little compared with the long past in the course of which we were formed and from which we result." 89 The habitus is a socially acquired predisposition to perceive, think, and act in a particular way, and this predisposition results from exposure to the particular events a person encounters. When the individual's position within the group becomes stable, the habitus becomes unconscious, "[y]et

\footnotetext{
86“A subjective, but not individual, system of internalized structures, schemes of perception, conception, and action common to all members of the same group or class." Pierre Bourdieu, Outline of A TheOry of Practice 86 (1977).

${ }^{87}$ This range of objective possibilities is called a field in Bourdieu's theory. A field is a social and professional context in which agents act and in which they are hierarchically put.

${ }^{88}$ BOURDIEU, supra note 86 , at 73 .

${ }^{89}$ Id. at 79 .
} 
we do not sense this man of the past, because he is inveterate in us; he makes up the unconscious part of ourselves." ${ }^{90}$ Habitus is the less visible continuity that flows beneath the easily observed discontinuities. Even though the political, legal, and economic system has changed drastically in the last thirty years, the underlying continuity forming power centers and subservience to them has endured.

Habitus as the underlying structure of the Slovak judiciary seems to rest in the inclination of the stronger players within the judiciary to form alliances to govern the judicial branch, as well as an inclination of the silent majority to submit to this power for pragmatic reasons. This habitus was present already in Austro-Hungarian legacy but strengthened after the harsh attack of the Communist Party on the independence of the judiciary, and the strength of this habitus followed through the period of the Communist regime and the subsequent transition period. A similar pattern is visible today. These inclinations are preserved in the judicial system as an "unconscious part of yesterday's man." The presence of internal pressure may seem as if it is the way things have always been and, therefore, it is.

\section{First Critical Juncture: A Road to Subservient Judiciary After 1948}

The process of the shift of the habitus of the judiciary will be presented first with the significant juncture during the period after World War II. This period saw a reversal of the tradition of interwar Czechoslovakia and a new adherence to an authoritarian power system.

The dissolution of the Czechoslovak judiciary happened quickly, although the judiciary was in a difficult position. The Czechoslovak judiciary after World War II faced various problems. There was no single cause compelling the judiciary to become the obedient servant of the Communist Party but a myriad of them. The judiciary suffered its undoing for not resisting political pressure, as the attack from the political power was enormous. The institutional framework of the judiciary was altered quickly. A change in personnel and a revolutionary interpretation of the law ${ }^{91}$ created the normative change in 1950, which followed the two year legal plan. ${ }^{92}$

Although the first Czechoslovak Republic-1918-1938-was a unitary state, the laws and structure of the court system differed between the Czech lands and Slovakia. The Czech lands received the law valid in the Austrian part of the monarchy prior to 1918, while Slovakia followed the legal system valid in the Hungarian part of the Austro-Hungarian Empire. This dual system continued throughout the entire existence of the first republic. ${ }^{93}$ Pre-war Czechoslovakia ceased to exist on March 14, 1939, and for the following six years, the Czech lands became a Protectorate under the Third Reich. Slovakia became a client state of Nazi Germany. ${ }^{94}$ After the war, Czechoslovakia was re-established as a continuation of the pre-Munich Czechoslovak Republic, ${ }^{95}$ and the Czech lands and Slovakia followed the tradition from the first republic of legal dualism. The dualism of law was established by a 1944 constitutional decree concerning the Restoration of Legal Order adopted by President Beneš and a 1944 regulation by the Slovak National Council (SNC). While the former declared continuity with pre-Munich

\footnotetext{
${ }^{90} I d$. at 79.

${ }^{91}$ The revolutionary concept of law did not consider law to be unconditionally binding if the telos of the socialism required different goal than the one that law planned. Law was meant to be the continuation of a revolution, albeit in a way legitimized by legal form.

${ }^{92}$ Legal two-year plan is a period between 1948-1950 in Czechoslovakia, during which the codification of main legal branches happened.

${ }^{93}$ JAN KUKLÍK, CZECH LAW IN HISTORICAL CONTEXTS 122 (2015).

${ }^{94}$ See Benjamin Frommer, Retribution as Legitimation: The Uses of Political Justice in Postwar Czechoslovakia, CONTEMP. EUR. HIST. 477 (2004).

${ }^{95}$ KuKLík, supra note 93.
} 
Czechoslovakia, where all the laws and regulations after 30 September 1938 are invalid, ${ }^{96}$ the latter declared that any law adopted after 30 September 1938 is valid unless contradictory to republican principles. ${ }^{97}$ The two parts of Czechoslovakia also prosecuted war crimes of its population under differing legal norms. After 1945 separate retributive courts were established for prosecution of war criminals, traitors, and collaborators. In Slovakia, the basis of these courts were a retributive regulation of the $\mathrm{SNC}^{98}$ - the legislative and executive body ${ }^{99}$ of wartime and post-war Slovakia, and in the Czech lands, the courts basis was a presidential decree. ${ }^{100}$

The differing court structures that existed before the war continued after $1945,{ }^{101}$ as a 1945 decree of the president concerning the interim adjustment of the judiciary was valid only for the Bohemian and Moravian-Silesian lands. ${ }^{102}$ As the Slovak Republic maintained its system of ordinary courts and after 1939 established its own apex court system, the post-war Czechoslovakia had two Supreme Administrative Courts and two Supreme Courts, located in Brno and Bratislava. ${ }^{103}$

The post-war period saw a myriad of debates on the structure of the re-established Czechoslovakia and Czechoslovak judiciary. ${ }^{104}$ Following the agreement of the Czechoslovak government with the SNC from 1945, the Supreme Administrative Court was supposed to sit in Bratislava, and the Supreme Court was supposed to have specialized panels with Slovak judges for laws valid in Slovakia, as well as two presidents, one Slovak and one Czech. ${ }^{105}$ In April 1946, a new agreement planned for the Supreme Court in Bratislava to be part of the Czechoslovak Supreme Court in Brno. However, the Communist Party enforced its centralism, and Czechoslovakia was again a unitary republic without autonomous regions. The dualism in the court structure was overcome in law in 1948, when three levels of courts were established - district, regional, and supreme-unifying the whole country. ${ }^{106}$

After the Communist Party came to power in Czechoslovakia, the independence of the judiciary was attacked on many fronts. The first was from the direct influence of the Ministry of Justice. The Minister of Justice after 1948, Alexej Čepička, ${ }^{107}$ faced the task of how "to remodel the judiciary into a weapon. . . [and] put it in service of working people."108 After the February coup, ${ }^{109}$ the judiciary experienced a deterioration of its independence. In the political trials of the

\footnotetext{
${ }^{96}$ JOZEF BEŇA, VỲVOJ SLOVENSKÉHO PRÁVNEHO PORIADKU 111 (2001).

${ }^{97}$ Stefan Luby, Obnova práva, 28-29 Pravny Obzor 1 (1945).

${ }^{98}$ Regulation no. 33/1945 Coll.

${ }^{99}$ Košice Governmental program of April 5, 1945.

${ }^{100}$ Decree of the President concerning the punishment of Nazi criminals, traitors and their helpers and concerning extraordinary peoples courts no. 16/1945 Coll. from 19.6. 1945.

${ }^{101}$ Michal Považan, Náčrt Vývoja Verejnej Správy Na Slovensku (1944 - 1948), 9 Historia ET TheORIA IURIS, 1, 150 (2017).

${ }^{102}$ Decree of the President 79/1945 Coll. concerning the interim adjustment of judiciary in the Bohemian and MoravianSilesian lands from August 19, 1945.

${ }^{103}$ Martin Skaloš, Vývoj súdnictva a jeho miesto v systéme orgánov štátu na našom území v rokoch 1945-1989, 475 DAYS OF LAW 2013, 310, 312 (2014).

${ }^{104}$ Prague agreements between SNC and Czechoslovak government on competence, the first signed in June 1945, the second in April 1946 and the third in June 1946. See Jan Rychlik, From Autonomy to Federation, in The End OF CzeCHOSLOVAKIA, 191 (1997).

${ }^{105}$ JAN KUKLÍk, DĚJINY ČESKOSLOVENSKÉHO PRÁVA 1945-1989, at 55 (2011).

${ }^{106}$ Act nos. 319/1948, 320/1948.

${ }^{107}$ Alexej Čepička-Minister of Justice of Czechoslovakia 2/25/1948-4/25/1950. He was also Minister of National Defense from 1950-1956. After 1956, he was dismissed from political and Party positions due to his political activities in previous years. In 1963, he was expelled from the Communist Party for his "major part in organizing political trials against Communists in the personality cult period."

${ }^{108}$ Jaroslav Vorel, Alena ŠimánKová \& LukÁš BabKa, ČEsKoslovenSKÁ Justice V Letech 1948-1953 V DOKUMENTECH PART I, 360 (2003).

${ }^{109}$ Between February 21-25, the Communist Party of Czechoslovakia took over political power in Czechoslovakia.
} 
1950s, ${ }^{110}$ judges were addressed by directives on surveillance of judicial activity. ${ }^{111}$ Archival documents from the Minister of Justice collection provide elaborated guidance on the goal of the criminal trial, which was "to help to re-educate our man." The Ministry of Justice issued directives on how to handle political trials to attain the most efficient outcomes. The surveys from proceedings were supposed to be "detailed and convincing, representing the professional level and real democracy of our people's judiciary." "12 One directive encouraged highlighting the beneficial role of popular justices in the proceedings. The directive labeled the trials "political" and dictated that political trials were supposed to be "evidence of the existence of anti-state element and ought to highlight the class struggle that is going on. The trials were supposed to demask the real nature of the anti-state elements and reveal their motivation to their criminal activity, elucidate the connection to imperialists - their employers." 113 According to the directive, the language used s supposed to be vague, in order not to give guidance on criminal activity for others. Naming particular organizations or states that could be identified in a defendant's case was prohibited, and it was stated that "all information intended to be printed must be discussed with the referent from the Ministry of Justice." 114

As the new goal was a concept of law that reflected the interest of the working masses, new method also needed to reflect this interest. The system of "telephone justice" 115 was established to transform the judiciary into a body that could be easily directed by the Party. It allowed political interference from the Ministry of Justice and ensured that "[a]ll issues of importance and political issues were discussed in collegium presided by the minister, with the presence of deputies."116 New methods of "collective work" were introduced. This term applied to the meetings of political deputies with deputies of courts and the prosecution. The institute of the "Security Committee," which consisted of five members who as a group became known as "the Security Five"117 [bezpečnostní pětky], was essential in subordinating the judiciary. In these "Fives," the decisions of cases at the State Prosecutor Office were delivered even before the court had heard the case. ${ }^{118}$ The role of "the Five" is visible in the case of Karel Landovský, who was sentenced by the State Court to life imprisonment on July 15, 1950. Once the case reached the Security Committee, it issued the command for the punishment to be changed by the Supreme Court to the death sentence. ${ }^{119}$

Statistics were also kept as a tool to control the fulfillment of work duties. Czechoslovak judge Otto Ulč, who had personal experience with the judiciary in the 1950s and who emigrated to West Germany and later to the US, writes about the quotas that all the judges had to meet:

The judge was thus faced with two unsought problems. He had to justify his existence by ensuring a full workload while at the same time disposing of this load at a rate deemed appropriate by the Ministry... The Ministry of Justice reached the zenith of its folly in 1959 when it

\footnotetext{
${ }^{110}$ Also known as "Show Trials" - the political trials in which the judicial authorities have already determined the guilt of the defendant in advance. The actual trial had as its only goal to present the accusation and the verdict to the public as an impressive example and as a warning to other would-be dissidents or transgressors. The law in these trials represented a state ideology. The judge, the prosecution, and the defense were acting on behalf of the government.

${ }^{111}$ Directive for new intelligence on courts, VÚA [Central Military Archive], collection: Čepička, vol. 28, archival unit 180.

${ }^{112} I d$; VÚA, f. Čepička, sv. 28, a. j. 180.

${ }^{113} I d$.

${ }^{114} I d$.

${ }^{115}$ Alena Ledeneva, Telephone Justice in Russia, 24 Post-SoviEt AfFAIrs, 324 (2008).

In Czech and Slovak sources often used "kabinetní justice - Cabinet judiciary"-interference of the executive to judicial power. In totalitarian states, including Communist Czechoslovakia, it was usual that initiation of criminal proceeding and the punishment was often decided by a political body. VOREL, ŠIMÁNKOVÁ \& BABKA, supra note 108, at 175 n.9.

${ }^{116}$ JAROSLAV VOREL, ŠIMÁNKOVÁ \& BABKA, supra note 108, at 363.

${ }^{117}$ Political committee coordinating cooperation of security forces in the region and regional Party organizations.

${ }^{118}$ Bayer report, VOREL, ŠIMÁNKOVÁ \& BABKA, supra note 108.

${ }^{119}$ Documentation on reasons of unlawfulness in the practice of Czechoslovak prosecutor office. Id. at 93.
} 
ordered the 're-organization of production quotas.' From then on, the entire spectrum of judicial activities was translated into norms, specifying the hours and even minutes required for execution. ${ }^{120}$

A special department handled the surveillance of the courts. Statistics were kept on such details as the judges' arrival and departure times and the number of cases they assumed. This data was then processed at the Ministry of Justice. ${ }^{121}$

Aside from the Ministry's direct attack, there were several indirect instruments used by the Communist Party to affect judicial decisions. One of the steps toward acquiring complete obedience to the justice system was to put it under the control of the prosecutor's office. This provided a more effective way for the Ministry of Justice to interfere in the courts by offering guidance to prosecutors in their actions rather than by attempting to control all proceedings directly. ${ }^{122}$ The prosecutor's office was filled with political cadres who became valuable assets for wielding political influence in trials. ${ }^{123}$ Bayer's report ${ }^{124}$ summarizes the effect of the Communist Party of Czechoslovakia's leading role in judicial decision-making, from the initial policy of installing political cadres to high posts to the eventual direct influence on the judiciary via the so-called cabinet judiciary. ${ }^{125}$

Building the telephone justice for political trials influenced the judiciary in general. The prosecutor was given more authority over the trial on behalf of the court. Judges became passive, mainly executing the motions of the prosecutor. The prosecutors were commanded on the indictment by "the Five," 26 and the court was expected not to question the indictment. The telephone justice represented the ultimate end of judicial independence. The judge's decision became a formulaic decision dependent on the political body and enforced by the prosecutor in the court.

The prosecutor's role in criminal proceedings is visible in the cases of the 1950s, particularly in cases where the court's expectation of confirming the prosecutor's indictment did not materialize. In some cases, the judge did not comply with the indictment of the prosecutor, as in the following case:

The case of the illegal organization Svetlana, the leader Opletal was supposed to be sentenced to death based on the indictment. During the trial, however, the court found his action as negligent and decided that a death sentence would not be appropriate. After the phone call of the chair of the department of the State Prosecutor in Brno, Mykiska, we were told that the sentence must be delivered according to the indictment . . . (judge) Pavelka adds: 'We were aware that we are deciding against the will of working people, but we did so because there was no other way.' ${ }^{\text {'27 }}$

\footnotetext{
${ }^{120}$ Ota Ulč, The Judge In A Communist State 42-48 (1972).

${ }^{121}$ Report on organization and method of work in judiciary, 4/29/1949, VÚA, f. Čepička, sv. 17, a. j. 113. See in supra note 108 , at 365 .

${ }^{122}$ SÚA [State Central Archive], f. ÚV KSČ [collection Central Committee of Communist Party of Czechoslovakia], Security Committee, vol.. I, unit. T 4474/56.

${ }^{123}$ Návrh soudců a prokurátorů pro zpracování státněprokurátorských a stát-něsoudních případů v jednotlivých krajích (1. dubna 1952), SÚA [State Central Archive], f. Generální prokuratura, [collection General Prosecutor Office], neuspořádáno [uncategorized], čj. [unit] $\mathrm{O} 45 / 52$. Even though the prosecutors were supposed to be loyal to the Party, for political trials it was demanded to favor the highest cadres on the list released by deputy of the Minister of Justice Karel Klos in 1952. See Odd. obrany a ochrany MS ČR, [Department of Defense and Security, Ministry of Justice of the Czech Republic, Collection Klosův archiv, box 130-36, a. j. [unit]] 131.

${ }^{124}$ Report of the Committee of the General Prosecutor Office, established on January 7, 1969. It delivered a report on unlawfulness in actions of General Prosecutor Office.

${ }^{125}$ SÚA, f. ÚV KSČ, Piller Committee, k. 13. Bayer report, VOREL, ŠIMÁNKOVÁ \& BABKA, supra note 108, at 92.

126 "The decision was told to the state prosecutor, usually in presence of the President of the State Court. Judges did not get any orders, however the motion of the prosecutor was the political decision.” Statement of the ex-vice Secretary of Justice Karel Klos (1948-1952) April 1, 1963. SÚA, f. ÚV KSČ, Piller Committee.

${ }^{127}$ Zářecký, P. Moc, právo a procesy. Národní archiv, f. ÚV KSČ, Piller Committee, k. 6, in VorEL, ŠIMÁNKOVÁ \& BABKA, supra note 108 , at 325 .
} 
A judge was not the mouth of the law but the pure mouth of power. His or her role in this system was to legitimate the political decision, even against the law. Sometimes these decisions were not coordinated ahead of time, as in the case of Milan Zajic:

On 22 December 1951, the trial against Ing. Milan Zajic and others took place in Sokolov. In this case, according to the meeting of "the Five," it was not supposed to be delivered the death sentence. However, in his final speech, prosecutor Dr. Barbaš asked for it. In the public trial, after a zealous speech from the prosecutor, the public expected the State Court to decide on the death sentence... After talking with the presiding judge of the panel on how the court is going to look like if not delivering the death sentence, the prosecutor decided to save the day by switching to the role of the defense and asked the court not to impose the death sentence, saying if the death sentence was imposed, 'It would have been madness.' 128

Further, right after the February coup in 1948, enforcing a personnel change was one of the priorities for the Communist power. It was not in the Party's interest to rely on judges loyal to the previous political regime, but it seemed impossible to replace all the judges. After World War II, the personnel situation was already difficult when the Czechoslovak judiciary was missing half of its pre-war judges. ${ }^{129}$ The State Secretary of the Ministry of Justice described the situation as such, "old bourgeoise court organization, laws on the judiciary from bourgeoise era and the vast majority of judges and prosecutors politically confused, part of them even hostile to our regime. Out of two thousand judges, only [one] percent were Party members."

To facilitate the personnel transformation of the judiciary, extraordinary law schools were established after February 1948. The goal was to solve the problem of the lack of personnel and secure political control over the courts. Therefore, the initial purge was not as dramatic as expected, ${ }^{130}$ as the modification of personnel took longer than in the $1950 \mathrm{~s} .{ }^{131}$ Furthermore, the Party did not aim to purge, but rather secure a strong control of, the judiciary. Therefore, the graduates of the so-called "Law School of Working Class" (Pravnická škola pracujících, PŠP), ${ }^{132}$ were mostly filling the positions of prosecutors or presidents of the courts. ${ }^{133}$ The "Law School of Working Class" consisted of the ex-proletarians, the only group with power and some political importance. It was known as "the mill to convert carefully selected proletarians with no prior advanced education into 'lawyers' in less than one year." 134 These graduates gradually took most of the positions of political significance, mainly within the Ministry of Justice, the Supreme Court, and in the prosecutors office. ${ }^{135}$ "By the end of the 1950s, eighteen out of nineteen Regional Prosecutors came from PŠP ... in the case of the chairs of the nineteen Regional Courts, there was no exception."136

\footnotetext{
${ }^{128}$ Documentary Committee GP ČSSR, JUDr. Karel Bayer, SÚA, f. ÚV KSČ, Piller Committee, k. 13., in VOREL, ŠIMÁNKOVÁ \& BABKA, supra note 108 , at 96.

${ }^{129}$ See Otakar Motejl, Soudnictví a jeho, in KomUnisticke Pravo 814 (Michal Bobek, Pavel Molek \& Vojtech Šimíček, eds., 2009). See also Zdeněk Kühn, Socialisticka Justice, in KomUnisticke PRAVO 825 (Michal Bobek, Pavel Molek \& Vojtěch Šimiček, eds. 2009).

${ }^{130} \mathrm{Kühn}$, supra note 129. Kühn mentions that ten percent left the judiciary at this point. In the statement of Karel Klos, State Secretary of the Ministry of Justice between 1948-1952, there is the same number-approximately ten percent of the judges. SÚA, f. ÚV KSČ, Piller Committee, (1. dubna 1963), uncategorized.

${ }^{131}$ ULČ, supra note 121 , at 16.

${ }^{132}$ Jaroslav Vorel, Alena Šimánková \& LukÁš BabKa, ČESKoslovensKá Justice V LeteCH 1948-1953 V DOKUMENTECH PART II 156 (2003).

${ }^{133}$ Report on Courses of The Law School of Working Class and Re-Location of the Cadres Within Judiciary (August 5 , 1950), SÚA, f. ÚV KSČ, Ústřední dělnická škola, a. j. 38.

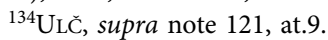

${ }^{135}$ Report on Courses of The Law School of Working Class and Re-Location of the Cadres Within Judiciary, supra note 133.

${ }^{136}$ ULČ, supra note 121 , at 9.
} 
Moreover, since 1957 the tenured positions of judges were abolished, and elections were installed to select new judges. This step helped to finalize the personnel change and confirm the subordination of the judiciary to political influence. Judges were elected by political bodies, including the National Assembly or local party committees, ${ }^{137}$ and were nominated by the National Front. ${ }^{138}$ First, in $1957^{139}$ the tenure was three years, then extended to four years in $1964,{ }^{140}$ and finally set at ten years in $1969 .{ }^{141}$ The short-term and recurring "retention elections" allowed political bodies to clear the judiciary of judges who did not conform to the Party's expectations and maintain control over personnel within the judiciary. Recalcitrant judges were simply not proposed as candidates in the next election. ${ }^{142}$ If an issue had to be addressed before the end of the term, the party committee could remove the judge, ${ }^{143}$ and disciplinary proceedings could be arranged for wayward judges to induce fear among members of the judiciary. ${ }^{144}$

The content of the law itself became an instrument for control of the judiciary. During the initial stages of the authoritarian regime beginning in 1948 and into the 1950s, judges were required to produce proactive, ideologically motivated judgments. ${ }^{145}$ Additionally, the preparatory work on legislation was no longer exclusively in the hands of the legal professionals, for collective organizations representing workers gained a strong position in deciding legislation. ${ }^{146}$ As the method of the judiciary of the liberal state was labeled as bourgeoise, a change was deemed necessary, for the judiciary needed to be rid of its bourgeoise character. ${ }^{147}$ This was also attained by shifting the role of the law, as "after February, the legal form was perceived as a formality, and it was used more for image and appearance than for quality social relations." ${ }^{48}$ The discontinuity is apparent. In the latter period, the former was clearly regarded with contempt. In Zářecky's report, ${ }^{149}$ the revolutionary approach to law used during this period from 1948 to 1953 is heavily criticized as illegal and unlawful, even though it was used by the same Party, as the one still in power when the report was written in 1968. The revolutionary concept of law from the 1950s is visible in the statements of the Minister of Justice, Kopriva, in 1963: "Yes, the arrests contravened the law, but no notice was taken of this at the time. It was only in later years that measures were taken to ensure respect for the law." ${ }^{150}$ The explanatory document on the criminal code adopted in 1950 is also explicit: "The role of the criminal code is to contribute to the degradation of the reaction effectively, and it must serve as a sharp knife of the working people against all enemies."151

The solidification of the law's application in a way that conformed to socialist legality became another useful instrument of control. A collection of judicial decisions was published regularly to

\footnotetext{
137 Act on election of judges par. 2-5, 36/1957 Coll.

138 During the Communist era in Czechoslovakia, 1948-1989, National Front was the vehicle for control of all political and social activity by the Communist Party of Czechoslovakia. These elections were just confirmation of Party candidates.

${ }^{139}$ Act. no. 36/1957 Coll. Par.2. This regarded the election of the judges for a three year period.

${ }^{140}$ Act. No. 36/1964 Coll. Par. 39.

${ }^{141}$ Act no. 156/1969 Coll. Par. 40

${ }^{142} \mathrm{ULC}$, supra note 121 , at 16.

${ }^{143}$ Act on election of judges par.10 36/1957 Coll.

${ }^{144}$ VOREL, ŠIMÁNKOVÁ \& BABKA, supra note 108 , at 98.

${ }^{145}$ Zdeněk Kühn, Ideologie aplikace práva v době reálného socialism, in KoMUNISTICKÉ Prâvo 62 (Michal Bobek, Pavel Molek \& Vojtech Šimíček, eds. 2009).

146"Fulfilment of the political goals of the judiciary could be secured, besides other measures such personnel purge, re-organization and cadre politics, by new working methods.” VOREL, ŠIMÁNKOVÁ \& BABKA, supra note 108, at 364 .

${ }^{147}$ Organization and method in the practice of the judiciary (April 29, 1949) VÚA, f. Čepička, sv. 17, a. j. 113.

${ }^{148}$ Piller report in VOREL, ŠIMÁNKOVÁ \& BABKA, supra note 108, at 285.

${ }^{149}$ Zářeckýs report is an analysis of trials in 1950s in Czechoslovakia, legitimized by judiciary. Its focus is on the role of judiciary in execution of the Communist Party plans.

${ }^{150}$ Zářeckýs report in Jiri Pelikan, The Czechoslovak Political Trials, 1950-1954: The Suppressed Report of The DUBCEK GOVERNMENT'S COMMISSION OF INQUIRY 138 (1971).

${ }^{151}$ Explanatory document on Criminal Code no. 86/1950 Coll. NS RČS 1948-1954, PRESS 160, PART NO. 4, https://psp.cz/ eknih/1948ns/tisky/t0160_04.htm (last visited Feb 5, 2021).
} 
help achieve this goal. Unification of judicial decision making is a positive goal, but in this instance, the collection was created by "politically mature" 152 professionals, and the collection did not serve only to unify but also to educate in a particular way. This instrument contributed to the shift in judicial decision-making, as during this time, the higher courts, especially the Supreme Court, were filled with "politically aware" judges. The goal of the control was to fight against bureaucratism, rigidity, and recklessness. ${ }^{153}$

Furthermore, under the influence of Soviet law, new institutions were adopted, such as the allowance of people with no legal training to serve as lay assessors. ${ }^{154}$ Their qualifications to become a judge laid in devotion and loyalty to the state. ${ }^{155}$ When deciding a case, their votes were equal to those of the professional judges. Even though the lay assessors were supposed to be a controlling mechanism for professional judges, their work's outcome was not as the Party might have expected. The first impressions were, surprisingly, that the lay judges were too lenient. ${ }^{156}$ Otto Ulč later wrote about the paradox of the helpful role of the lay assessors: "I have never felt myself to be a victim of the assessors, and I doubt whether any other judge has ... It was generally agreed among the judges that the assessors could be utilized as a valuable source of knowledge concerning matters about which a lawyer would know next to nothing."157

The judiciary became subservient as an "executive mechanism of political bodies and state security." 158 The judiciary gave the processes the branding of legality and professionalism, although the judiciary members knew that they were contributing to the breach of Czechoslovak law. The Piller Committee $^{159}$ concludes that the top representatives of the judiciary knew about the nature of the political trials, about the process of how decisions were made but did not act against it, so "the argument that they were wrongly informed cannot stand against these allegations ... the accountability of the judiciary is great, but differentiated. It is the accountability of some members, not the judiciary as whole." 160 The Committee did not throw all of the lawyers into one category. Those who were to blame from the so-called "cabinet judiciary" included the creators of the system, like "the Minister of Justice, his deputies, higher representatives of the ministry, the Prosecutor General, the President of the Supreme Court, the State Prosecutor, and the President of the State Court."161

Simultaneously, this way of operation would not survive without obedient servants-the prosecutors and judges. The judiciary held a system of dependency wherein judges were dependent on a smaller center within the judiciary, which were themselves dependent on the political center of the Communist Party. To begin, the Ministry of Justice illegally decided on cases when the Party's

\footnotetext{
${ }^{152}$ VOREL, ŠIMÁNKOVÁ \& BABKA, supra note 108 (Organization and method in the practice of the judiciary (29. dubna 1949) VÚA, f. Čepička, sv. 17, a. j. 113).

${ }^{153} I d$.

${ }^{154}$ Until 1948, it was common in Czechoslovakia to have jury trials in criminal proceedings as the lay instrument.

${ }^{155}$ An application to the Communist Party could prove this devotion. In 1949, the Law Schools of Toiling People were opened and the loyalty to the Communist Party with the "right" political attitude became a stronger requirement than the competence of the judge.

${ }^{156}$ Report for the Minister of Justice from May 4, 1949, VÚA, f. Čepička, sv. 21, a. j. 143.

${ }^{157}$ ULČ, supra note 121 , at 23.

${ }^{158}$ Piller Committee, SÚA, f. ÚV KSČ, k. 19.

${ }^{159}$ In 1968, when the Communist regime underwent a wave of self-criticism of its nature in previous two decades, a committee named after the chairman, Jan Piller, was appointed. Its goal was to bring a testimony on the events between 19481954. Even though it was not successful in finishing its initial plans due to the interruption of the reform process in Czechoslovakia in 1960s, it provides important archival information. The Committee was set up by the Central Committee of Communist Party of Czechoslovakia to complete Party rehabilitation. The Members included: Jan Piller, Jaroslav Frýbert, Milan Hladký, Leopold Hofman, štefan Infner, Karel Kaplan, František Krajčír, Marie Miková, Oldřich Rákosník, Jiří Rzpel, Mária Sedláková, and Jindřich Uher.

In English, see Jiri Pelikan, The Czechoslovak Political Trials, 1950-1954: The Suppressed Report of the Dubcek GOVERNMENT's COMMISSION OF INQUiRY 138, 12 (1971).

${ }^{160}$ Accountability of the judiciary (author and date not specified) SÚA, f. ÚV KSČ, Piller Committee, k. 19. JAROSLAV Vorel, Alena ŠimÁnKová \& LuKÁš BABKA, supra note 108, at 337.

${ }^{161} I d$. at 338 .
} 
interest was at stake. Therefore, the Ministry demanded not only the obedience of the judges but of the advocates as well. The Ministry furthered the superior role of the prosecutor in the criminal proceeding. Judges decided on death sentences without knowledge beyond a reasonable doubt, and prosecutors put innocent people on trial knowing that their criminal trial did not meet the standards of a fair trial. The Piller Committee report concludes that apart from state security and political leadership, the judiciary helped realize the political trials. As written in Kolder's report from 1963, ${ }^{162}$ the judiciary was facing an overwhelming institutional attack. Elements of this attack included subordinating the judicial decision, allowing the Minister of Justice to interfere with proceedings, limiting judges in the supervision of investigations, subordinating the court to the prosecution, making the prosecutors indictment binding for the court, and limiting the options for the criminal defense. ${ }^{163}$

The justice system was turned upside-down. The separation of powers between legislative, executive, and judicial branches was formally maintained when in reality, it ceased to exist. ${ }^{164}$ Power was not mutually shared. The mechanisms of maintaining legality, like courts, parliament, public opinion, and free elections, were disabled. In their place, "[a] new system of the control was maintained by power groups, that controlled the obedience to the directives they issued. The Constitution formally covered all. ${ }^{165}$ The prosecution office controlled judges." 166

This Party's definition of fundamental rights is explicit in its exceptional character: "Fundamental rights are by the socialist state stipulated, and in the Constitution is written an option that allows every citizen to choose the ways and limits of their behavior and to use the benefits of the system in the personal or public interest." 167 The rights are applicable to everybody, under the condition that the socialist state recognizes them as legitimate. The judge does not interpret what an individual's rights encompass but rather, guesses what the political power would prefer.

The Communist Party created a new habitus of the judiciary through a relatively quick and shocking attack. A closed, fearful, and pragmatic judiciary, which appeared to be ashamed of its position in the system, kept what was happening within it a secret. The new habitus of the judiciary is reflected in Piller Committee's conclusion: "On the whole, members of the judiciary played a theatrical performance of their undignified role and, with their actions, contributed to the degradation of legal consciousness and the authority of law." 168

\footnotetext{
${ }^{162}$ Kolders committee - second committee on rehabilitations of the unlawfully convicted in trial in 1950 s, established in August, 1962.

${ }^{163}$ Zpráva o činnosti justičních orgánů v období politických procesů. Report on justice system in time of political trials - Kolder report, (March 19, 1963). SÚA, f. ÚV KSČ, Komise II, sv. 30, a. j. 507. . VOREL, ŠIMÁNKOVÁ \& BABKA, supra note 108. The nature of the regime is visible in the place of the advocacy in the new system from the quote of Minister of Justice Čepička: "Some advocates must have gone crazy and they defend the accused, while their task is to support the indictment." In this system, where nothing can stay outside Party control, judiciary was no exception. KAREL KAPLAN, ČESKOSLOVENSKO: 1: V LETECH 1945-1948, at 52 (1991). This political influence on judiciary was no secret to the members of the Central Committee, as they were informed of the facts on how trials worked. As Zařecky's report, as a part of Piller's Committee claims - in 1968, when the report was written, the methods and actions of state security, prosecution, and judiciary were publicly known. Communist Party elites knew latest by July 1953 from the Bacilek report that in actions of State security were included criminal methods. ÚV KSČ z 28. 7. 1953. SÚA, f. ÚV KSČ, 02/5, sv. 1, a. j. 165. "After 1953 were Dr. Barák, Švach, and Litera appointed to the Committee of the Central Committee of the Communist Party of Czechoslovakia in order to investigate some of the political processes in years 1949-1952."

The report of the Barak Committee was submitted on September 18, 1957, and they claimed their goal to be "supporting the dictatorship of the proletariat." ÚV KSČ z 18. 9. 1957. SÚA, f. ÚV KSČ, 02/2, sv. 153, a. j. 201.

${ }^{164}$ KAPLAN, supra note 163, at 38. See Eduard Taborsky, The Administration of Justice in a "People's Democracy", 49 AM. Pol. SCI. Rev. 405 (1955) For an example of how similar the wording of the Constitution of 1948 is to the wording of the Constitution of 1920.

${ }^{165}$ KAPLAN, supra note 164 , at $51-53$.

${ }^{166} I d$. at 52 .

${ }^{167}$ Vojevodin L.D: Svetova Socialisticka Soustava A Statni Vystavba V Evropskych Socialistickych Zemich (1977), at 293.

${ }^{168}$ Závěrečná zpráva tzv. Pillerovy komise (1969) SÚA, f. ÚV KSČ, Piller Committee, k. 41A. Piller report in VOREL, ŠIMÁNKOVÁ \& BABKA, note 108, at 286.
} 


\section{E. Second Critical Juncture-Harabin Era}

The second presented critical juncture in the Slovak judiciary is when Štefan Harabin held the seat of Minister of Justice, 2006-2009, and later the seat of the President of the Supreme Court and the Chair of the Judicial Council, 2009-2014. This juncture shows the judiciary in its fragile years after the Ministry of Justice ceased controlling the judges' careers and when the judiciary acquired broad autonomy. It was an opportunity to start building the institution of the judiciary that would fulfill the wager of the liberal democratic state. Unfortunately, the habitus of power structures within the judiciary crashed under this optimistic expectation.

The period between 1989 and 2006 also offers an interesting study, but this Article's goals and limits will be presented briefly, with some attention given to the process and nature of establishing the supreme body of judicial legitimacy-the Judicial Council.

\section{Personnel Changes of the Judiciary and the Persisting Habitus}

The judiciary experienced significant personnel changes after 1989. The reasons varied, but some judges left due to the judiciary's low reputation and moved to better-paid positions in advocacy or business. ${ }^{169}$ Some were afraid of the lustration process. ${ }^{170}$ The courts lost many judges from the previous regime and, at the same time, started to grow after 1989. In three years, the courts grew from 747 judges serving in Slovakia to 1,095 judges in Slovak courts. ${ }^{171}$ The number of judges who left or stayed on the bench is missing, however:

Given the "softer" stance of Slovaks toward the Communist regime, it is likely that the ratio of Communist-era judges in Slovakia is even higher than the relatively high number in the Czech Republic. However, the Slovak post-split scenario significantly differs from the Czech one since dealing with the past within the judiciary is not an issue that attracts particular attention in Slovakia ... As a result, the Slovak judiciary in 1993 looked very much the same as the Slovak judiciary before the Velvet Revolution ... there have not been any calls for further purges within the judiciary. ${ }^{172}$

However, the personnel change does not seem to be essential in the "Threema scandal," as none of the accused were appointed before 1989. Still, although it is now 31 years since the fall of Communism in Slovakia and most of the pre-revolution judges have retired, the habitus of subserviency to power centers is alive; "hence even judges appointed after 1989 were socialized and educated in a system deaf to the idea of independence, preventing the judiciary from undergoing a 'mental' transition to proper democratic values." 173 The understanding of the Central and Eastern European judges after 1989 was characterized by Michal Bobek as a judicial culture which embodies the perception that judges are simply "well-paid civil servants," where judges see themselves as

\footnotetext{
${ }^{169}$ In 2001, in the Czech Republic, approximately sixty percent of the judges were appointed after 1989. In Hungary, it was seventy percent of the judges appointed after 1989. See Zoltán Fleck, Judicial Independence and Its Environment in Hungary, in Systems of Justice in Transition: Central AND EASTERn EuROPEAN ExPERIENCES Since 1989 (Jiři Přibaň, Pauline Roberts \& James Young, eds. 2003). See also Eliška Wagnerová, The Position of Judges in the Czech Republic, in SysTEMS OF JUSTICE IN Transition: Central and Eastern European Experiences since 1989, at 163-79 (Jiři Přibaň, Pauline Roberts \& James Young, eds. 2003).

${ }^{170}$ Lustration was supposed to prevent the former agents or collaborationists of the secret service of the Communist state, leaders of the Communist Party, and graduates of Soviet ideological universities from entering the government, administration, military, public media, and public companies established by the government.

${ }^{171}$ Martin Kovanič \& Samuel Spáč, Vyrovanie sa s minulostou v sudcovskom stave, in NEDOTKNUTELNí? 45 (Erik Láštic \& Samuel Spáč eds. 2017).

${ }^{172}$ KosAř, supra note 15 , at 248.

${ }^{173}$ Spáč, Šipulová \& Urbániková, supra note 18, at 1743.
} 
"subservient technocrats" who lack the confidence to make judicial decisions on their own. ${ }^{174}$ The judiciaries have achieved structural independence while still lacking mentally independent judges. ${ }^{175}$

\section{Road to Independent Judiciary}

Between 1998 and 2005, Slovakia implemented substantive reforms to strengthen judicial independence, which became a central focus of the EU after adopting the EU Copenhagen Criteria. The quality of the mechanisms applied towards achieving the independence of the judiciary became a significant point in evaluating candidates in the accession process. ${ }^{176}$ As the EU claimed to be built on a willingness to share values, ${ }^{177}$ the candidate countries had to meet specific requirements if they aspired to join. Slovakia worked enthusiastically to achieve an independent judiciary to fulfill the accession criteria.

The Constitution ensured the separation of the judiciary from other governmental branches by establishing the Judicial Council as the highest body of judicial legitimacy, which facilitated the judiciary's independent position to other state authorities. ${ }^{178}$ The Council managed all major powers overseeing the careers of judges. The Slovak Republic established the Judicial Council's model based on what is in literature labeled the Euro-model. ${ }^{179}$ This can be described as:

[A] model of judicial Council that meets five basic criteria, namely entrenching that body in the Constitution, ensuring that judges have at least parity in that body, vesting the real decision-making power with that body, transferring most "personal competences" regarding a career in the judiciary to that body, and selecting the Chief Justice or its equivalent as the chairman of the judicial Council. ${ }^{180}$

The Judicial Council's role within the Slovak framework was quite opaque at the beginning of its existence. ${ }^{181}$ As Spáč writes: "On one hand, it is true that a greater level of [judicial selfgovernment] helped to insulate the judiciary from direct political pressure. On the other hand,

\footnotetext{
${ }^{174}$ Bobek, supra note 18, at 100 (2008).

${ }^{175} \mathrm{Id}$. at 110 .

${ }^{176}$ Cristina E. Parau, The Drive for Judicial Supremacy, in Judicial IndePENDENCE IN Transition 619 (Anja Seibert-Fohr
} ed. 2012).

${ }^{177}$ Article 2 of the Treaty on European Union:

The Union is founded on the values of respect for human dignity, freedom, democracy, equality, the rule of law and respect for human rights, including the rights of persons belonging to minorities. These values are common to the Member States in a society in which pluralism, non-discrimination, tolerance, justice, solidarity and equality between women and men prevail. Id.

${ }^{178}$ See supra note 29 on Constitution of the Slovak Republic Art. 141(a); Act No. 185-2002 Coll; On the Judicial Council of the Slovak Republic. Art. 141(a), to the Slovak Constitutional Act No. 90/2001 Coll; Judgement of the Constitutional Court of the Slovak Republic, III. US 79/04. Judicial Council has the authority over the selection and appointment of judges, the promotion of judges, the evaluation of judges, disciplinary and ethical matters, the training of judges, the administration and management of courts, the protection of the image of judges, the provision of opinions to other powers of the State, the co-operation with other relevant bodies on national, European and international level, the responsibility towards the public: Transparency, accountability, reporting.

${ }^{179}$ Bobek, supra note 84; Bobek \& Kosař, supra note 18.

${ }^{180}$ KosAr̆, supra note 15 , at 399.

${ }^{181}$ KosAř, supra note 15 , at 263 :

$[\mathrm{M}]$ ost Slovak judges still do not see the difference between judicial boards on the one hand and the Judicial Council on the other, and they think of the Judicial Council as an organ of self-government of the judiciary. Members of the Judicial Council no longer hold this opinion - according to them the Judicial Council is a constitutional organ that is the source of the legitimacy of the judiciary. 
it allowed for an unexpected capture of the judiciary 'from inside' by rewarding the allies of those in power and punishing their critics." ${ }^{82}$ Although the self-administration was set in place to shield judges from political pressure, the cases of influencing still flourished; "the only difference [was] that before it could at least be maintained that these things were carried out by the corrupt political elite and because of system deficiencies. Now it is the judges themselves who run the show." 183

After implementing the judicial reform, a surprising development followed. The governmental change after the 2006 elections brought to power parties with less enthusiasm towards the modern, European management of judicial affairs but with stronger sentiment for the past. When Štefan Harabin became the Minister of Justice as the nominee of the HZDS, the party of the now-infamous politician Vladimir Mečiar, he was still known as the opponent of the Judicial Council. David Kosař writes:

The most intriguing [puzzle] is that those Slovak judges who initially opposed the judicial council model took over the judicial Council eventually. Štefan Harabin, the President of the Slovak Supreme Court in 1998-2003, was in fact the most vocal critic of the [Judicial Council] during the parliamentary debates in 2000-2001 and in the first years of its operation. He was not responsible for putting the model on. Yet he soon adjusted to the new model, managed to capture the [Judicial Council] in 2009, and started to use the mechanisms of judicial accountability at his disposal as a tool of power. ${ }^{184}$

When Harabin was leaving the office of the Minister of Justice in 2009 on his election as President of the Supreme Court, he altered the President of the Supreme Court and Judicial Council's position to grant himself overview and control of the entire judiciary.

The Judicial Council gradually became widely criticized for non-transparent and arbitrary decisions and for prosecuting judges who were not loyal to the hierarchy while promoting those who were. Inefficiency, corruption, arbitrary decision-making, suspicious appointments, low public trust, and abuse of power within the judiciary became typical for the justice system. Scholars and public officials also accused the Judicial Council of per rollam voting ${ }^{185}$ and secrecy and criticized them for holding meetings in inconvenient locations that dissuaded the public and journalists from attending them. ${ }^{186}$

While in theory, the Council of Europe and the European Union's proposals could have been helpful for traditional democracies with more stable institutions, the emerging democracies in the CEE used these proposals to produce an isolated, largely unaccountable judiciary led by judges bent on corrupt, self-favoring action. ${ }^{187}$

Samuel Spáč offers an interesting characterization of the reforms implemented in the twenty-first century in Slovakia, including their emphasis on using the Judicial Council as the guard of judicial independence and results of that attempt:

\footnotetext{
${ }^{182}$ Spáč et al., supra note 18 , at 1764 .

${ }^{183}$ Bobek, supra note 18.

${ }^{184}$ KosAř, supra note 15 , at 9 :

The creation of the Judicial Council thus cannot be explained by the hegemony preservation thesis or the insurance theory. It was not a skillfully executed plan of the pre- Judicial Council political or judicial elites adopted in order to preserve their powers. To the contrary, the beneficiary of the judicial council model was neither its author nor its proponent, but its major critic.

${ }^{185}$ Voting done by the so-called "per rollam"- by letter-means that it is voting without calling a meeting (for example, by correspondence), which meant that nobody could attend the Judicial Council's meetings. KosAr̆, supra note 15 , at 263.

${ }^{186} I d$.

${ }^{187}$ James E. Moliterno, Lucia Berdisová, Peter Čuroš \& Ján Mazúr, Independence Without Accountability: The Harmful Consequences of EU Policy Toward Central and Eastern European Entrants, 42 FordHAM INT'L L. J. 481, 534 (2018).
} 
The necessity of establishing the rule of law, reinforced by Central and Eastern European countries' desires to be accepted in the EU, created a tension between the goal of achieving judiciary independence and the post-Communist context they had to deal with. These judiciaries were severely affected by the legacies of previous regime and created unfavorable conditions for the creation of institutions of judiciary independence. Creation of judicial councils in such a culture may have resulted in encapsulation of the judiciary and its separation from the society, because of elitist and corporatist tendencies that were here inherently present. ${ }^{188}$

However, the position of judicial elites was, to some extent, still dependent on political allies. The election of the president of the Supreme Court in 2009 was a merger of political and judicial power, during which Harabin was elected by the Judicial Council as incumbent Minister of Justice. The joint position of the presidency of the Supreme Court and Chair of the Judicial Council was strengthened by Harabin himself as Minister of Justice. The election in 2014 was also influenced by political actors who decided to end the reign of Harabin and elected his former ally but current rival Daniela Švecová. ${ }^{189}$ It was apparent that moving the competence to elect the president of the Supreme Court from the National Assembly to the Judicial Council did not abolish the influence of political power on the selection of leading figures within the judiciary. The political leaders remain interested in who is being elected to Chief Justice, and they still get involved informally in the selection process. ${ }^{190}$

\section{Formally independent but Mentally Dependent}

This habitus of the judiciary led by Harabin allowed powerful elites within the judiciary to secure influence through rewards and punishments. This process was protected from outside critique by a series of defamation lawsuits filed by judges. Within the judiciary, it was secured through disciplinary proceedings, financial bonuses, and anti-discrimination lawsuits. ${ }^{191} \mathrm{With}$ all these steps, Harabin created the image, generally accepted among judges, that he was a champion for an independent judiciary. The result of the reforms passed before 2006, and the developments that followed was the creation of a formally and constitutionally independent judiciary filled with dependent judges. ${ }^{192}$ Harabin and the group of judges around him became the new inspector in the panopticon lodge. Harabin acted like a monarch who was building a network of power through loyal nobles. With a policy of carrots and sticks, he took advantage of a subservient judiciary's existing habitus and turned its obedience and loyalty toward himself.

\section{Isolation from outside, loyalty from within}

First, there were several instances when the judiciary bent the rules or exploited loopholes for their own sake to create an untouchable, elite group. The most visible instances of this were the cases in

\footnotetext{
${ }^{188}$ Samuel Spáč, Judiciary Development After the Breakdown of Communism in the Czech Republic and Slovakia, CEU POL. SCI. J. 234, 257 (2014).

${ }^{189}$ David Kosař \& Samuel Spáč, Post-communist Chief Justices in Slovakia: From Transmission Belts to Semi-autonomous Actors?, 13 Hague J. RulE L. 107, 127 (2021). On reasons of Harabin's toxicity and loss of political support see Tomáš Lalík, Tracing Constitutional Changes in Slovakia Between 2008-2016, 58 Hungarian J. Legal STUd. 117, 133 (2017).

${ }^{190}$ Kosař \& Spáč, supra note 189 , at 127.

${ }^{191}$ Furthermore, the re-establishment of judicial candidates. This was largely appreciated among the judges, as it gave courts —and its presidents and judicial boards_-much more control over the selection of their new colleagues. In 2012, as many as one in five judges had at least one family member working in the judiciary. Moreover, by temporary assignments of judges from courts to the Ministry of Justice, where they participated in the preparation of judicial policies. See Spác et al., supra note 18 , at 1751 .

${ }^{192}$ See Bobek \& Kosař, supra note 18.
} 
which Slovak judges interpreted the legal framework on the freedom of speech ${ }^{193}$ to award themselves the privileged position of being protected from public criticism. A sad testament to this period was the ban on criticizing judges, which was sanctioned with high financial penalties. Not only did it degrade the reputation of the judiciary among the public, but it also created a chilling effect in public media, as criticism became an expensive choice of action.

Examples of legal manipulation started in the period after Harabin's first presidency of the Supreme Court. Harabin sued a publishing house for interference with his right to the protection of a reputation. In the case in which Harabin sued the publisher Petit Press, the district court argued: "Facts mentioned in the articles encourage the reader to conclude that the applicant committed the immoral, undignified and illegal activities while serving as a judge." ${ }^{194}$ The appellate court confirmed the decision but focused on arguing the necessity of the protection of impartiality and the independence of the judiciary: "[T]here are no doubts, the trust of the public in the legal system and judiciary, protection of the authority and independence of the judiciary is essential...." Harabin was awarded 33,000 EUR in damages. ${ }^{195}$ Harabin also sued the publisher Perex for defamation. The district court argued that "the defamatory statements appeared when the applicant was applying for re-election to the Chair of the Supreme Court." ${ }^{\prime 96}$ The appellate court confirmed that "a member of the judiciary is not a public figure and does not have to face the lower standard of protection against criticism ... on the contrary, as the judiciary has a specific position in the separation of powers, it is the most sensitive branch in regards to the trust of the public."197 Harabin was awarded 100,000 EUR. ${ }^{198}$ Interest in defamation lawsuits among judges was widespread during the time of Harabin's "reign," and their success was surprisingly high. ${ }^{199}$

Second, the policy of the carrot and stick within the judiciary became viable for enforcing loyalty among members. One of the political victories of Harabin was the case of anti-discrimination lawsuits against the state, during which judges of the ordinary courts sued the state based on wage discrimination. The action was built upon the previous decision of the Constitutional Court, which claimed that the existence of the Special Criminal Court was unconstitutional. ${ }^{200}$ In its reasoning, the Constitutional Court mentioned that the difference in salaries was obviously disproportionate. ${ }^{201}$ This argument allowed all judges to file an anti-discrimination claim and ask for the difference between their salary and that of the Special Court judges during the period of that court's existence. More than 700 judges filed this lawsuit against Slovakia. ${ }^{202}$

The period of Harabin's presidency of the Supreme Court and the Judicial Council is also known for the controversial increase of salaries. Even though Slovak judges were paid, on average, much better than their Polish, Hungarian, and Czech counterparts, as Bojarski and StemkerKöster write, "[i]t is remarkable that in the period of 2004-2008, the court budgets and judges' salaries have risen at a rate and percentage that is unequal in comparison to other countries." 203

\footnotetext{
${ }^{193}$ For further reading on criticism of judges: David Kosař, Freedom of Speech and Permissible Degree of Criticism of Judges in the Jurisprudence of European Court of Human Rights and U.S. Courts, CENTRAL EUROPEAN UnIVERSITY (Nov. 22, 2007), http://www.etd.ceu.hu/2008/kosar_david.pdf.

${ }^{194}$ District court Bratislava I, judgment of June 18, 2007, 19C/139/2005.

${ }^{195}$ Regional court Bratislava, judgment of December 1, 2011, 6Co 392/2007.

${ }^{196}$ District court Bratislava V, judgment of March 31, 2005, 42 Coch 2/03.

${ }^{197} I d$.

${ }^{198}$ Regional court Bratislave, judgment of December 15, 2005, 9Co 213/05.

${ }^{199}$ Peter Wilfling \& Eva Kováčechová, Sloboda prejavu a žaloby na ochranu dobrej povesti, VIA IURIS (2011), https://viaiuris. sk/wp-content/uploads/2017/08/publikacia-sloboda-zaloby.pdf.

${ }^{200}$ This court was established in 2004 by the law 458/2003 Z. z., on Special Court and Special Prosecutor Office, to hear cases of official corruption and those related to high-ranking government and political figures and organized crime. The Constitutional court ruled the Special Criminal Court to be unconstitutional in decision PL. USS 17/08.

${ }^{201}$ Decision of the Constitutional Court of the Slovak Republic no. PL. US 17/08.

${ }^{202}$ See more on anti-discrimination lawsuits in Lukasz Bojarski \& Werner Stemker Koster, The Slovak judiciary: Its Current State and Challenges, Bratislava: Open SOC'y Found. 110 (2012).

${ }^{203} I d$. at 110 .
} 
Furthermore, a very generous policy of remuneration benefits and special bonuses for selected judges peaked under Harabin. ${ }^{204}$ In 2009, when Harabin moved to the Supreme Court from the Ministry of Justice, he reinstated the policy of giving salary bonuses. According to media outlets, bonuses of more than 52,000 EUR were awarded to Harabin himself, and over 40,000 EUR went to his former allies Daniela Švecová and Jana Bajanková. ${ }^{205}$

Furthermore, loyalty among the Slovak judiciary members was ensured by the harsh disciplinary accountability of judges who expressed a critical opinion about the judicial hierarchy. One judge was prosecuted and suspended for writing a letter to the President of Slovakia referring to the unsatisfactory situation in Slovak courts. The court president where this judge sat accused the judge of defamation, false allegations, and insults. According to the court president, the judge failed in maintaining the principles of judicial ethics and proposed the punishment of dismissal of the judge. The first instance disciplinary panel decided to reduce the judges salary to fifty percent for the upcoming six months. The same judge faced a disciplinary motion earlier for revealing information from a criminal investigation. Although the disciplinary panel denied the motion, the Minister of Justice, Štefan Harabin, immediately suspended the judge for the maximum possible period of two years. ${ }^{206}$ Another judge was punished for providing the court a truthful testimony that proved inconvenient for another highly influential judge. ${ }^{207}$

The disciplinary panels' staffing was another sign of accumulation of powers within the small group of members of the judiciary. The composition of a disciplinary panel was decided by the Judicial Council, which also had the right to appoint and the various panels' presidents. ${ }^{208}$ The disciplinary proceeding might be initiated by the court president, the Minister of Justice, the national ombudsman, or a president of a regional council of the judiciary. At the same time, the court presidents could be members of the Judicial Council, "meaning that as a presidents of a court they could instigate a disciplinary proceeding against a judge and - at the same time-as a member of SNCJ (Judicial Council) decide on the composition of the disciplinary court which would decide on the case against these judges." ${ }^{209}$ Simultaneously, the Minister of Justice could enter the proceedings and suspend the judge for a maximum of two years. Another issue of the disciplinary proceedings became the double-standard: Judges who were close to the judicial hierarchy faced none or very lenient sanctions, while others were suspended and suggested for removal from their judicial appointments for the same or less severe wrongdoings. ${ }^{210}$ The disciplinary proceedings often failed to meet the essential criteria for a fair trial. ${ }^{211}$ In a nutshell, after the parliamentary election of 2006 and Harabin becoming the Minister of Justice, the disciplinary judiciary selectively levied the harshest sanctions for actions that were normally sanctioned mildly or not at all. ${ }^{212}$ Selective reassignments of cases, overwhelming caseloads, and reassignments of judges to panels outside their area of expertise were other

\footnotetext{
${ }^{204}$ See more on remuneration and bonuses case in $I d$. at 111.

${ }^{205}$ KosAř, supra note 15 , at 326.

${ }^{206}$ Pavol Žilinčík \& Samuel Spáč, Selektivna zučtovatelnost, in NedOTKNUTELNî? 165 (Erik Láštic \& Samuel Spáč, eds. 2017).

${ }^{207}$ Bojarski \& Stemker Koster, supra note 201, at 103.

${ }^{208} \mathrm{Id}$. at 101 .

${ }^{209} \mathrm{Id}$. at 101 .

${ }^{210}$ Žilinčík \& Spáč, supra note 205.

${ }^{211}$ As the reaction to the silence of the majority of judges about this development, in 2009, more than 100 Slovak judges, out of 1300, signed a petition called "Five Sentences," claiming judges had to work in an "atmosphere of fear," and the judicial authorities were seeking to punish them for expressing their opinion. Other judges in defense of the judicial leadership accused the signatories of Five Sentences of politicization. The situation was so tense that it prompted foreign ambassadors to attend the disciplinary hearings in the courtrooms. See Žilinčík \& Spáč, supra note 205, at 171.

${ }^{212}$ Žilinčík \& Spáč, supra note 205, at 170.
} 
tactics used to punish judges. ${ }^{213}$ In the most extreme cases, the cumulative effect of the practices of court presidents amounted to overt bullying. ${ }^{214}$

All these examples of limiting the freedom of expression to criticize the judiciary, promoting anti-discriminatory lawsuits, providing special bonuses for loyal judges, and enforcing disciplinary measures for those who act disloyally are symptomatic of a judiciary that was freed from the oppression of political power but became a slave to new masters. The independence based on the Euro-model Judicial Council did not fulfill expectations:

Not only did the Judicial Council fail to eliminate possible undue influence over the judiciary exercised through the administration of professional careers, but under Harabin's chairmanship, accountability mechanisms suffered even more deficiencies than before and became tools for rewarding his allies and punishing his critics and opponents. These practices, reminiscent of "mafia-like structures," led to a deep divide within the judicial branch, while increasing the salience of judicial issues among the public and politicians. ${ }^{215}$

The concept of judicial independence was misused and abused by some members of the judiciary, who shielded their unethical, unlawful, or status-quo-defending behavior with the cloak of independence:

Judicial independence has been used, for instance, to explain why to disregard the established case law of higher courts and thus render the judicial process almost unpredictable; why not display the full name of deciding judges in published decisions of the court; why it is impossible for judges to regularly publish their assets and incomes; why there cannot be any legal obligation for judges to follow continuous education after their appointment; or why only do judges have to keep 13th and 14th salaries ${ }^{216}$ when the government is trying to push through cuts in public savings ... ${ }^{217}$

\section{F. Current Situation and Is There a Way Out?}

Over time, Harabin "was eventually becoming more and more toxic and, finally, the entire political sphere stood united in the view that Harabin should be removed." ${ }^{218}$ He lost power in 2014 after the chair of the Judicial Council was separated from the president of the Supreme Court. His power center was slowly reduced, and those previously loyal to him gradually denounced him and the alliances that they held with him. For some time, it seemed that the trust of the public was recovering, and polarization within the judiciary was at least not becoming worse.

\footnotetext{
${ }^{213}$ David Kosař, Politics of Judicial Independence and Judicial Accountability in Czechia: Bargaining in the Shadow of the Law Between Court Presidents and the Ministry of Justice, 13 Eur. UNION Const. 96, 118 (2017).

${ }^{214}$ KosAř, supra note 15, at 339. Polish experience of abusive disciplining of judges after the adoption of the "Muzzle Law"- a bill amending the Act on the Organization of Ordinary Courts, the Act on the Supreme Court, and the Act on the National Council of the Judiciary from 20 December 2019-before the Polish Parliament, which tightened the disciplinary liability system reminds the infringement of free speech of judges. However, the Polish situation goes even further than Slovak as the "Muzzle Law" sanctions submitting preliminary questions to the CJEU and following its recent judgment. Moreover, while the Slovak case portrayed the capturing of the judiciary by judicial elites, from the inside, the Polish one represents the attack from the political power. Katarzyna Gajda-Roszczynialska \& Krystian Markiewicz, Disciplinary Proceedings as an Instrument For Breaking the Rule of Law in Poland, Hague J. Rule L. 451, 480 (2020).

${ }^{215}$ Spáč et al., supra note 18 , at 1755.

${ }^{216}$ Judgement of the Constitutional Court of the Slovak Republic, from December 11, 2013, PL. US/2011. This decision denied an option of cutting judges' salaries, when the Slovak economy was in recession, based on the argument of independence of the judiciary.

${ }^{217}$ Bobek, supra note 64, at 113.

${ }^{218}$ Spáč et al., supra note 18 , at 1767.
} 
Between 1989 and 2001, when the political inspector in the panopticon was gradually abandoning the inspector's lodge, the inspector's lodge became occupied by one of the judges. It was likewise wrong to expect that in 2014, a habitus characterized by the creation of power clusters would be erased and that the judiciary would fundamentally change. Moreover, the persistence of old habits is more likely when young candidates without prior experiences are selected and appointed to the position of a judge, as it is in the Slovak system. This may lead to candidates' embeddedness in the system, and the establishment of informal networks of gratitude and loyalty $^{219}$ that support the informal practices of dependence on the judiciary.

Corruption in the role of the judicial elites, such as the presidents of the courts and the highpositioned judges in the Supreme Court, was apparent during the Threema scandal. The judges who were accused in the police operations Tempest, Gale, and Weeds, came from five courts: Two district courts in Bratislava, the regional court in Bratislava, the regional court in Žilina, and the Supreme Court. In all but one court, the president of the court was allegedly involved in criminal activity that concerned the judges of that court. In total, eleven out of nineteen accused judges were current or former court presidents or vice-presidents. ${ }^{220}$ It seems that the central power within the judiciary represented by Harabin and his followers did not disappear but was transformed into several centers situated at particular courts. Court presidents became quiet, inconspicuous actors, who maintained power while the Judicial Council was disempowering ministers of justice. ${ }^{221}$

\section{Inconspicuous Court Presidents}

Court presidents, as one of the traditional pillars ${ }^{222}$ of the Slovak court administration, played a crucial role during state socialism, as well as through the late 1990s and into the 2000s. ${ }^{223}$ Even after the implementation of the Judicial Council, they were able to maintain a similar level of power as before 2012, ${ }^{224}$ as they could sit in the Judicial Council and eventually capture it. Before the reforms enacted in 2011, the Minister of Justice had strong control over the court presidents, with the power to appoint and remove them at her own discretion. After 2011, the Minister became limited by the recommendation of the committee, although the Minister decides on a majority of representatives who make up the selection committee. Data gathered since 1998 show that all the ministers of justice used their competence to remove and appoint court presidents extensively. ${ }^{225}$ All ministers of justice claimed they acted to depoliticize the judiciary, but all of them wanted to fight politicization with their candidates as court presidents. ${ }^{226}$

\footnotetext{
${ }^{219}$ Samuel Spáč, The Illusion of Merit-Based Judicial Selection in Post-Communist Judiciary: Evidence from Slovakia, Problems of PosT-Communism 1, 9 (2020). Such a pattern of judicial appointments may lead to lack of personal courage of the judge, as well. See Bobek, supra note 18, at 108 (2008).

${ }^{220}$ Pavol Žilinčík, Etika v sobě, kodex ve skř́ini, soudci ve vazbě, 11-12 SOUDCE, 15 (2020).

${ }^{221}$ David Kosař, Politics of Judicial Independence and Judicial Accountability in Czechia: Bargaining in the Shadow of the Law Between Court Presidents and the Ministry of Justice, 13 Eur. Const. L. Rev. 96, 115 (2017).

${ }^{222}$ More on court presidents in CEE context see MARIA Popova, Politicized JUSTICE IN EMERGING DEMOCRACIES: A STUdY of COURTS IN Russia AND UKraine (2012); DANIEla Piana, Judicial ACCOUNTABILITIES IN NEW EUROPE: FROM RULE OF LAW TO QUality of Justice (Routhledge ed. 2010); David Kosař, Perils of Judicial Self-Government in Transitional Societies: Holding the Least Accountable Branch to Account (2016). David Kosař \& Samuel Spáč, Post-communist Chief Justices in Slovakia: From Transmission Belts to Semi-autonomous Actors?, 13 Hague J. Rule L. 107 (2021); Adam Blisa \& David Kosař, Court Presidents: The Missing Piece in the Puzzle of Judicial Governance, 19 German L. J. 2031 (2018).

${ }^{223}$ Kosař \& Spáč, supra note 222, at, 119.

${ }^{224}$ Judgment Pl. ÚS 2/2012.

${ }^{225}$ David Kosař \& Samuel Spáč, Predsedovia Súdov: Od Ministerských "Spojok" K Autonómnym Aktérom, in NedotKNUTELNî? 145 (Erik Láštic, Samuel Spáč, eds. 2017).

${ }^{226}$ Ján Čarnogurský (1998-2002) replaced thirty percent of district court presidents (DCP) and fifty percent of regional court presidents (RCP). Daniel Lipsic (2002-2006), twenty-eight percent of DCP and 12.5 percent of RCP, Stefan Harabin fifty-seven percent of DCP and fifty percent o RCP, Lucia Zitnanska (2010- 2012) forty-eight percent of DCP and seventy-five percent of RCP and Tomas Borec forty-eight percent of DCP and 62.5 percent of RCP. See Id. at 145 .
} 
Court presidents' competences are significant in personnel matters regarding judicial careers as well as in the administration of the court. These competences include the power to initiate disciplinary proceedings, the management of the work schedule, jurisprudential power, financial power, ambassadorial power, and media power. ${ }^{227}$ Before 2011 , district courts had very strong influence on the selection of new judges, as the Judicial Council often only rubber-stamped the agreements. ${ }^{228}$ Slovak court presidents have, in comparison to other jurisdictions in the CEE, extensive power in judicial careers and in jurisprudential matters, intermediate power in administrative and financial areas, and rather minimal power in ambassadorial and media matters. ${ }^{229}$ Although inconspicuous, court presidents are still powerful. ${ }^{230}$ And there is no doubt that political actors are still interested in influencing the judiciary by exerting control over candidates for the chief justice position and, even, the presidents of ordinary courts. ${ }^{231}$ Control over court presidents allows the political power to shape the long-term appearance of the judiciary. As the ministerial power over the removal of the court presidents is still popular among ministers of justice, it may appear that political influence has never disappeared, and court presidents still serve as transmission belts, ${ }^{232}$ although there is not yet enough data to substantiate such a claim. ${ }^{233}$ This political interest in court presidents led scholars to question why court presidents are so valuable to political leaders. ${ }^{234} \mathrm{~A}$ replacement of a court president may not indicate immediate control over judiciary, which could more efficiently be achieved with a court-packing strategy ${ }^{235}$ for apexcourts or the replacement of the chief justice and changing the Judicial Council. ${ }^{236}$ Still, the removal of court presidents is less visible and enables continual control over the judiciary. Loyal court presidents may serve as a valuable source of information for political leaders, which helps the Justice Minister to suppress potential revolts before they start. ${ }^{237}$

Despite the involvement of the court presidents of Bratislava and Žilina courts in judicial corruption and the formal and informal networks of control that the Minister of Justice wields over the presidents and judges who serve at the Ministry of Justice, the participation of political leaders in judicial corruption has not yet been confirmed. Such a connection would not be surprising if it were proven. What is obvious is the strong position the court presidents hold over judicial careers and disciplinary matters, which, in particular conditions and hands, may lead to a hierarchical control of courts. The court presidents serve as another knot, holding power over judges and potentially furthering private interest if it becomes part of an informal network.

\section{Reactions to Threema}

The Threema scandal elucidated only one network of inappropriate relations between judges, business leaders, and politicians, as the police investigations in this scandal were limited to the courts that appeared in the Threema communication. The discovery of the leads that enabled

\footnotetext{
${ }^{227}$ See Blisa \& Kosař, supra note 222, at 2055.

${ }^{228}$ Spáč et al., supra note 18 , at 1750 .

${ }^{229}$ Blisa \& Kosař, supra note 222, at 2059.

${ }^{230}$ KosAR̆, supra note 15 , at 300 .

${ }^{231}$ Kosař \& Spáč, supra note 225.

${ }^{232} I d$.

${ }^{233}$ See id. at 151 .

${ }^{234}$ Blisa \& Kosař, supra note 222, at 2033.

${ }^{235}$ David Kosař \& Katarina Šipulová, How to Fight Court-Packing?, 6 CONST. STUD. 133 (2020).

${ }^{236}$ Kosař \& Spáč, supra note 222.

${ }^{237}$ Blisa \& Kosař, supra note 222, at 2034.
} 
police to investigate these courts happened quite fortunately when international journalists and Europol experts working on the case ${ }^{238}$ could break the encryption on Kočner's smartphone. ${ }^{239}$ Even though police operations are enormous, they seem to uncover only a fraction of the Slovak judiciary problem. There may be more to uncover in the pockets of the Slovak judiciary.

Although the reputation of the Slovak judiciary was bad before Threema, and judicial corruption was rumored to occur often, the first reactions to the Threema revelations were that corruption in judiciary is only a personnel failure and not a systemic problem. Focusing on the reactions to the Threema scandal by representatives of the judiciary is useful for understanding the current state of the habitus in the Slovak judiciary. In October 2019, the President of the Judicial Council, Lenka Praženková's, response was quite critical of political interference in the judiciary. ${ }^{240}$ Later, in March 2020, when 13 judges were accused of corruption, Praženková admitted the possibility of corruption in individual judges, but the focus on interference with the independence of the judiciary as a whole was still prioritized in her statement:

... [T] he situation in the judiciary is not good. However, it is not possible to accept any means that would unlawfully affect the personality rights of a person and, in addition, the independence of the judiciary. At the same time, the President of the Judicial Council is watching long term attempts to violate the principles of a democratic state and rule of law from some of the future government politicians, which is absolutely unacceptable. ${ }^{241}$

This reaction showed that the chairwoman's fear of investigation into the judges' affairs is stronger than her disappointment at their failures.

After thirteen judges in Bratislava were exposed as participants in the scandal, other judges initially refused to generalize on the behavior of judiciary members; instead, they called for awareness of the threat of interference from the politicians of the government newly elected in March 2020. A group of almost seventy judges ${ }^{242}$ released a statement that the failures were in the individuals, and the politicians and media were together fueling the discussion. Characteristically, the judges wrote that they must stand against the attempts by the forces of politics and media to sensationalize the matter. ${ }^{243}$ This reaction was very similar to that of the judges fifteen years ago when attempting to isolate the judiciary from any form of public criticism. ${ }^{244}$

Later, individual judges, not representative bodies, have unexpectedly delivered signs that accountability is a virtue. First, the Council of judges at the Trnava Regional court condemned the activities of the judges involved in the Threema scandal and the weak reaction of the repre-

\footnotetext{
${ }^{238}$ See Marína Urbániková \& Lenka Haniková, Coping with the Murder: The Impact of Ján Kuciak’s Assassination on Slovak Investigative Journalists, JOURNALISM PRAC. 1, 3-4 (2021).

${ }^{239}$ IT experts testified on Threema, Kočner had many questions, THE SLOVAK SPECTATOR (Feb. 7, 2020), https://spectator. sme.sk/c/22319713/kuciak-murder-trial-europol-expert-brought-to-court.html.

${ }^{240}$ Predsednička súdnej rady reaguje na aktuálne dianie v slovenskej justícii, SÚdNA RADA SLOVENSKEJ REPUBLIKY (Aug. 26, 2019), https://www.sudnarada.gov.sk/predsednicka-sudnej-rady-reaguje-na-aktualne-dianie-v-slovenskej-justicii/.

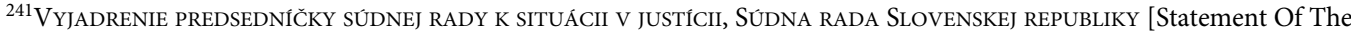
President Of The Judicial Council Of The Slovak Republic On The Situation In The Judiciary] (Mar. 13, 2020), https://www. sudnarada.gov.sk/data/files/1157_ts-english-16032020.pdf.

${ }^{242}$ Veronika Prušová, Politici a médiá nám kazia meno. Čast'sudcov po operácii Búrka hladá vinníkov mimo svojich radov, DENNíK N (Mar. 27, 2020), https://dennikn.sk/1823747/politici-a-media-nam-kazia-meno-cast-sudcov-po-operacii-burkahlada-vinnikov-mimo-svojich-radov/.

${ }^{243}$ Lucia Berdisová, Slovenské Právnické Profesie V Kríze: Vyjde Po Búrke Slnko? [Slovak Legal Professions in Crisis: Will The Sunshine Again After The Storm?], in Metamorfózy Práva Ve Střední Evropě 2020: Právo A Krize [Metamorphoses Of Law In Central Europe 2020: Law ANd Crisis] (Jermanová, ed., 2021).

${ }^{244}$ Žilinčík \& Spáč, supra note 205.
} 
sentative bodies of judicial autonomy. ${ }^{245}$ Afterward, their colleagues from the District Court in Prešov joined them in their call, when twelve judges published a call titled "Screen Us!"246

The shift from an offensive attitude against executive power and media towards a deeper understanding of the structural problem of Slovak judiciary came only with the change of the Judicial Council chair after the election in June 2020, when the new chairman Ján Mazák was elected after Praženková was forced to step down. Mazák concluded:

Less than [twenty] percent of the public having trust in the independence of the judiciary is not just a number. It means much more. One of the crucial pillars of the rule of law-the judiciary-is essentially not independent. More specifically, it is independent in less than one-fifth of the expected capacity. The dysfunctional independence of the judiciary significantly devalues the rule of law. The devalued rule of law directly threatens the interests of Slovakia as a member state of the European Union. It hinders the proper fulfillment of international obligations. It creates an atmosphere of distrust. It brings with it unwanted costs. If justice does not work, then everyone will doubt whether to come to us to invest, work, produce, do science and research, and, at the same time, the people of the country will leave-to a better and fairer world. Let's not look for a specific culprit. We're all a little guilty . . . ${ }^{247}$

This shift in rhetoric from one of the Slovak judiciary representatives, the Chairman of the Judicial Council, and the plea of taking steps toward "self-admission of guilt" by the judiciary itself, provoked outrage among a group of Slovak judges. ${ }^{248}$ The Slovak case's failure lay in the judiciary's inability to face and react to the situation earlier, even though it possessed all the necessary instruments to do so, as they had been incorporated into law since 2001. The habitus of the judiciary, rooted in a tendency to create power centers which seek control over the judges on the one side, and judges' lack of resistance towards such tendencies on the other, seems to be a problem that is not to be solved by merely passing more policies to prevent interference from the representatives of the executive power.

From a survey among members of legal professions conducted by scholars in Slovakia in the fall of $2020,{ }^{249}$ it seems that most of the respondents agreed on a sufficient level of regulation for legal professions, but they doubt the enforcement of the rules. The habitus of closed elite clubs that do not welcome public accountability is the main objection to overcome following the improper handling of and reaction to the Threema scandal. ${ }^{250}$ The reaction of judges to the Threema scandal was seen as insufficient by twenty-six percent, and somewhat insufficient by sixty-two percent of respondents. On the question of which changes in legislation would foster an adequate reaction, judges' responses were as follows: "[N]o changes necessary/they would not be helpful" was selected by [twenty-seven] percent of respondents, "the presumption of innocence must be followed now and it is too early to conclude" by eleven percent, and "no changes could help, because the problem is a question of moral character" by ten percent. They held similar views toward the

\footnotetext{
${ }^{245}$ Trnavskí krajskí sudcovia sú presvedčení, DenNík N (Oct. 23, 2019), https://dennikn.sk/minuta/1628583/.

${ }^{246}$ Sudcovia Okresného súdu v Prešove vyzývajú kolegov na prerušenie výkonu funkcie, TLAČOVÁ AGENTƯRA SLOVENSKEJ REPUBLIKY - TASR.SK (Oct. 23, 2019), https://www.tasr.sk/tasr-clanok/TASR:20191023TBB00450; Sudca v štandardnej spoločnosti, SUDCOVIA “ZA OTVORENú jUSTíciu” (Mar. 12, 2020), http://www.sudcovia.sk/en/component/content/article/9slovenske-kategorie/dokumenty/2890-sudca-v-standardnej-spolocnosti.

${ }^{247}$ Vyhlásenie predsedu Súdnej rady SR k porovnávaciemu prehladu EÚ v oblasti justície z roku 2020, SÚDNA RADA SLOVENSKEJ REPUBLIKY (Jul. 12, 2020), https://www.sudnarada.gov.sk/vyhlasenie-predsedu-sudnej-rady-sr-k-porovnavaciemu-prehladu-euv-oblasti-justicie-z-roku-2020/.

${ }^{248}$ Patrik Števík, Pôsobenie pána Mazáka vo funkcii predsedu súdnej rady je nedôstojné, DENNíK N (Jan. 19, 2021), https:// dennikn.sk/2232040/posobenie-pana-mazaka-vo-funkcii-predsedu-sudnej-rady-je-nedostojne/. Followed by the response of judges and ex-judges. Mária Tóthová, L’udmila Babjaková \& Mária Laufová, K článku sudcu Števíka o predsedovi súdnej rady Mazákovi, DeNNíK N (Jan. 21, 2021), https://dennikn.sk/2235302/k-clanku-sudcu-stevika-o-predsedovi-sudnej-rady-mazakovi/.

${ }^{249}$ Lucia Berdisova, Zuzana Dlugosova \& Jan Mazur, Coping with Threema: How Do Lawyers Perceive Their Biggest Corruption Scandal?, 103 Právny ObZor Special Issue 63 (2020).

${ }^{250}$ Id. at 71 .
} 
question of what would prevent further corrupt behavior like that uncovered in the Threema scandal, with the largest group of nineteen percent of judges responding that only different values of individuals and society can prevent such behavior and sixteen percent believing that rules on entrance into professions and focus on the character of the person could prevent the situation.

Similar responses were provided for questions on possible changes in laws that would foster adequate sanctioning of corrupt behavior. Of the judges surveyed, twenty-seven percent think changes are not needed and would not help, while eighteen percent think that the existing legislation must be applied and enforced. In conclusion, almost half of the participants were exceptionally skeptical about legislative changes. They believed that the core of the problem lay in the values and morality of society and individuals and that a legal rule cannot enforce ethical behavior. ${ }^{251}$

The lack of the judiciary's understanding of its habitus might soon result in an unwanted outcome. Recent constitutional reform of the judiciary ${ }^{252}$ supposedly set more bureaucratic accountability checks in place. ${ }^{253}$ An amendment of the Constitution limited the Constitutional Court of the Slovak Republic in its review of the amendments of the Constitution. ${ }^{254}$ This step enabled the parliamentary majority to take steps to amend the normative framework on ordinary courts and the Judicial Council via constitutional amendment that would not fall under review of the CCSR. The following changes were made. First, the composition and powers of the Judicial Council were reformed. The Judicial Council finally acquired its constitutional definition, as it was previously only implied by the CCSR. ${ }^{255}$ The Judicial Council became "the constitutional body of judicial legitimacy." 256 More controversial may seem the upending of the $\operatorname{CCSR}^{257}$ and the allowance of the dismissal of a member of the Judicial Council even before the expiration of his or her term of office without a need to provide reasons. ${ }^{258}$ Second, the change on functional immunity of the judge was introduced, as judges could not only be disciplinarily but also criminally liable for a legal opinion that is arbitrary, unsubstantiated, or otherwise ignorant of the wording of legislation or

\footnotetext{
${ }^{251} I d$. at 80 .
}

${ }^{252}$ Slovak Constitution no. 422/2020. Extended analysis of the constitutional reform of the judiciary in Slovakia may be found in James Moliterno \& Peter Čuroš, Recent Attacks On Judicial Independence: The Vulgar, The Systemic, And The Insidious, in this Special Issue.

${ }^{253}$ On November 5, the Slovakian Minister of Justice announced a new court-map for Slovakia. Ministerka spravodlivosti predstavila novú súdnu mapu, Ministerstvo Spravodlivosti Slovenskej Republiky (Nov. 23, 2020), https://www.justice. gov.sk/Stranky/aktualitadetail.aspx?announcementID=3050. Likewise, this reform will reduce the number of first-instance courts from fifty-four to thirty, and the number of appellate courts from eight to three. The primary object of the reform is also to improve the effectiveness of the courts. The Minister of Justice plans to have at least three judges at each court for every kind of agenda. This ambition seems to show the Minister's priorities: the fight against corruption, and the support of transparency. It seems to be reactionary to previous years' failures. See Dissimilar Similarities, VERFASSUNGSBLOG (Nov. 26, 2020), https://verfassungsblog.de/dissimilar-similarities/.

${ }^{254}$ See Slovak Constitution no. 460/1992, art. 125, par. 4. This step was a reaction to the decision of the CCSR no PL US. 21/ 2014, where the CCSR interpreted implicit material core of the Constitution to block the attempt of the parliamentary majority to set the vetting procedure of the judges. The National Assembly put it explicitly to the Constitution that the CCSR does not have the competence to review the compliance of constitutional acts with constitutional acts or constitutional acts with a Constitution.

${ }^{255}$ First was Judicial Council defined as "sui generis" body of judicial autonomy (I. ÚS 62/06), later as "highest authority of judicial power" (PL. ÚS 102/2011), body of guarantee of independence of the judiciary, US Pl 2/2012, and Pl US, $2 / 2018$.

${ }^{256}$ Art. 141(a), para. 1., Slovak Constitution. This perception of the body of legitimacy was there among the academics and members of the Council even before. However, most Slovak judges still do not see the difference between judicial boards on the one hand and the Judicial Council on the other, and they think of the Judicial Council as an organ of self-government of the judiciary. See Kosař, supra note 172, at 263.

${ }^{257}$ The CCSR decided in judgment PL. ÚS 2/2018 from September 19, 2018 :

Therefore, if the legislation is (so far) silent on the grounds for dismissal of a member of the Judicial Council, the principle applies that there is no objective possibility to dismiss members of the Judicial Council before the expiration of their term. Granting the bodies creating members of the Judicial Council a constitutionally unacceptable power subjectively, and thus arbitrarily removing members of the Judicial Council from office before the expiry of their term of office, would mean absolute negation of their constitutionally guaranteed term of office.

${ }^{258}$ Art. 141(a), para. 5, Slovak Constitution. 
case law. ${ }^{259}$ Third, the establishment of the Supreme Administrative Court and a new court map was proposed. The President of the CCSR shared his concerns about the limitations of CCSR, ${ }^{260}$ and the CCJE provided objections to the above-mentioned amendments, where it criticized the constitutional amendment for interfering with judicial independence. ${ }^{261}$ Nonetheless, the chairman of the Judicial Council supported the changes as necessary for maintaining the legitimacy of the judiciary. ${ }^{262}$ Furthermore, some parts of the reform were received with almost no controversy, including the reform of the terms of constitutional court judges, ${ }^{263}$ the introduction of an age limit for the termination of the function of a judge of the ordinary and constitutional courts, and the inspections of property relations of judges and their judicial competence. ${ }^{264}$

\section{More Bureaucratic Accountability?}

Nonetheless, strong bureaucratic accountability does not address the informal networks that enable adherence to the players' private interests, often in illegal ways. The group of judges in the Bratislava courts and the Supreme Court who were charged as the part of the network working in the interest of Marian Kočner, was uncovered mostly by coincidence, following the public uproar after the murders of Ján Kuciak and Martina Kušnírova. Although bureaucratic accountability and criminal liability are strong motivators for affecting behavior, it is not preferable from a long-term perspective for securing an independent judiciary. Instead, the focus should be put on building a judiciary whose judges seek independence as a virtue of the profession.

In a system that focuses on the formal barriers against interference and formal requirements that limit judicial behavior, accountability is necessarily built on "a negative or positive consequence that an individual judge expects to face from one or more principals (from the executive and/or the legislature and/or the court presidents and/or other actors) in the event that his behavior and/or decisions deviate too much from a generally recognized standard." 265 Therefore, in systems focused on the institutional separations of state power, which are characteristic of the CEE countries that implemented the formal requirements of the EU and the COE to achieve independence of the judiciary, it is typical to focus on the "institutional relationship between judges

${ }^{259}$ Art. 148, para. 4, Slovak Constitution. See more in Marek Domin, Judicial Reform in Slovakia: How to Deal With "Bad" Judges?, IACL-IADC BLOG (Jul. 30, 2020), https://blog-iacl-aidc.org/2020-posts/2020/7/30/judicial-reform-in-slovakia-howto-deal-with-bad-judges. The abolishment of judicial immunity for decision-making was removed from the amendment to the Constitution, but the Criminal Code was amended with a new crime called "abuse of law."

${ }^{260}$ Veronika Prušová, Ústavný súd zrejme príde o kompetenciu, ktorú si sám privlastnil. Koalícia reaguje na kontroverzné rozhodnutie z minulosti, DENNí N (Nov. 24, 2020), https://dennikn.sk/2156633/ustavny-sud-ma-prist-o-kompetenciu-ktorusi-sam-privlastnil-koalicia-reaguje-na-kontroverzne-rozhodnutie-z-minulosti/.

${ }^{261}$ The CCJE publishes an opinion about the new provisions relating to the Judicial Council of Slovakia, CONSULTATIVE COUNCIL OF EUROPEAN JudGes (Dec. 9, 2020), https://www.coe.int/en/web/ccje/news/-/asset_publisher/8Wd6RJfyNLaO/ content/the-ccje-publishes-an-opinion-about-the-new-provisions-relating-to-the-judicial-council-of-slovakia.

${ }^{262}$ List predsedu Súdnej rady Slovenskej republiky prezidentke Konzultatívnej rady európskych sudcov, SÚDNA RADA SLOVENSKEj REPUBLIKY (Dec. 16, 2020), https://www.sudnarada.gov.sk/list-predsedu-sudnej-rady-slovenskej-republikyprezidentke-konzultativnej-rady-europskych-sudcov/.

${ }^{263}$ See art. 134 and $154(\mathrm{~g})$, par. 9-11 of the Slovak Constitution. After the constitutional court crisis starting in February 2019, in October 2019, were candidates finally elected in the National Assembly and appointed by the president. One of the criticized facts was that the majority of the former judges finished their terms simultaneously, which created pressure on the National Assembly and the need for eighteen candidates from whom nine new judges of the CCSR would be appointed. The amendment established the continuous change at the CCSR for the next generation of the judges of CCSR. See also Drama or Serenity? Upcoming Judicial Appointments at the Slovak Constitutional Court, VerfassungSBLOG (Jan. 29, 2018), https:// verfassungsblog.de/drama-or-serenity-upcoming-judicial-appointments-at-the-slovak-constitutional-court/.

${ }^{264}$ Art. 141(a), par. 6/h, of the Slovak Constitution. In reaction to the mentioned decision of the CCSR 21/2014, the amendment enables the Judicial Council to exercise active supervision over the fulfillment of the conditions of judicial competence by its autonomous conduct and verification without substantial interference by another public authority, as before the decision $21 / 2019$ this role was supposed to do by the National Security Authority.

${ }^{265}$ KosAr̆, supra note 15 , at 57 . 
and forums which can hold them to account (accountability as a mechanism), rather than the propriety of the behavior of judges (accountability as a virtue)."266

Formally perceived mechanical accountability then opens the door to the centralization of power for those who decide on those accountable. Setting focus on bureaucratic accountability has led to accountability perversions in the Slovak system, including accountability avoidance, simulations of judicial accountability, and selective accountability. ${ }^{267}$ Bureaucratic accountability does not focus on the long-term outcomes of the judiciary. It does not primarily plan on educating towards independence and accountability as a virtue. ${ }^{268}$ If mental independence exists, accountability can be discussed as a virtue, as well. However, the discourse of independence and accountability is currently focused on insulation from interference by the electorate and by the elected legislative and executive branches with a judge's decision making, which is created primarily by structural aspects of government to ensure that state actors are deterred from influencing impartial judicial decision-making. It is not focused on the reason for seeking judicial independence to guarantee the judicial process to be appropriately insensitive to arbitrary and irrelevant influences in order to be able to weigh the evidence and apply the law in particular cases in an unbiased manner.

There is no doubt that mechanical accountability is, of course, an instrument used to increase trust. But in this approach, there is a contradiction as mechanical accountability seeks trust through a willingness to accept control. The profession that represents the wager of the political system will then be put under stricter control. More bureaucratic instruments of accountability produce more hierarchical dependency and hinder mental independence. Consequently, bureaucratic accountability, on its own, does not solve the problem of corruption, as the breach of the rules may happen via informal practice and be covered by the inspector of the panopticon.

The only way to fight corruption is to be unwilling to tolerate corruption among judges by themselves. This goal takes much more time and effort than merely achieving political consensus on another control mechanism within the judges' normative framework. It requires changes in education and judicial training to coach judges in resisting pressure. The change needs to move towards accountability as a virtue of the judge that is rooted in adherence to professional ethics and well-explained reasoning in judgment.

The practical solution must be more elaborate than creating more bureaucratic mechanical accountability. The goal is to create an independent habitus of the judges who are aware of their role in delivering justice. It is essential to start with this as early as during legal education, highlighting the strong personalities among judges who have stood against pressure, teaching about the importance and role of the rule of law, and providing training for establishing resilience against inappropriate pressure.

\section{G. Conclusion}

This Article focused on the persistence of informal institutions within the Slovak judiciary, and explained why the mere implementation of institutional reforms was insufficient for ensuring the independence of judges from political or private interests. The starting point is the critical juncture of 1948 when the Communist Party subordinated the judiciary through various systemic steps that destroyed independence, personal as well as structural. This formal subordination was supposed to vanish with the structural after 1989 through the implementation of systemic reforms of the

\footnotetext{
${ }^{266} I d$. at 265. Mechanisms of accountability include "contingent circumstances" of judicial accountability, such as: One, ex post mechanisms that affect court officials, judges in general, entire courts, or the judiciary as a branch of government rather than individual judges; two, screening mechanisms; three, transparency mechanisms; four, quasi-appellate mechanisms; and five, criminal mechanisms and genuinely pathological mechanisms of judicial accountability.

${ }^{267} I d$. at 333 .

${ }^{268}$ Mark Bovens, Two Concepts of Accountability: Accountability as a Virtue and as a Mechanism, in ACCOUNTABILITY AND EUROPEAN GOVERNANCE 28-49 (2014).
} 
judiciary. But the persistence of the informal institutions hindered the shift towards a trustworthy independent judiciary. When the judiciary was supposed to become independent and autonomous, it was captured from the inside by Štefan Harabin, who was supported by the political players. His actions from the position of the Chief Justice, Minister of Justice, and Chairman of the Judicial Council strengthened the existence of an informal practice of informal networks, subservient judges, and power centers within the judiciary. The Czechoslovak judiciary became a prisoner in the panopticon after 1948, and in Slovakia, it has been pursuing the same path, as only the networks have been amended. Since the Communist Party left the formal inspector's lodge, the new inspectors and network partners have become oligarchs, influential figures, and associations within the judiciary - as well as political players, often disguised by their unofficial representatives in the judiciary. After the revelations of the Threema scandal and the change of government in 2020, it seems that the approach is changing with new leadership of the Judicial Council. The Judicial Council, including the representatives from the pool of judges, admits that the problem is systemic and that informal practice leading to judicial corruption is widespread. This Article concludes that installing more measures for bureaucratic accountability may not be enough to weaken the informal institutions that contravene the formal rules and hinder the goals of an independent judiciary and judges. Changes to the legal education and judicial ideology that shape the self-perception of judges are needed.

Cite this article: Čuroš P (2021). Panopticon of the Slovak Judiciary - Continuity of Power Centers and Mental Dependence. German Law Journal 22, 1247-1281. https://doi.org/10.1017/glj.2021.62 